\title{
Production of bay anchovy Anchoa mitchilli in Chesapeake Bay: application of size-based theory
}

\author{
Sukgeun Jung*, Edward D. Houde \\ University of Maryland Center for Environmental Science, Chesapeake Biological Laboratory, 1 Williams St., PO Box 38, \\ Solomons, Maryland 20688, USA
}

\begin{abstract}
To evaluate and quantify productivity of abundant bay anchovy Anchoa mitchilli in the Chesapeake Bay ecosystem, daily stock biomass, production, and contribution to predators of youngof-the-year (YOY) bay anchovy were estimated from May 1995 to October 2000, based on tri-annual midwater trawl collections. Empirical allometric relationships were applied to develop size-dependent growth and mortality estimates. Estimated annual mean stock biomass of YOY bay anchovy was lowest in $1996\left(17 \times 10^{3}\right.$ metric tons [t] wet weight $)$ and highest in $2000\left(64 \times 10^{3} \mathrm{t}\right)$. Estimated YOY production varied inter-annually by a factor of 4 , ranging from $167 \times 10^{3} \mathrm{t}$ in 1996 to $697 \times 10^{3} \mathrm{t}$ in 2000. Daily stock biomass levels usually peaked in mid September, while daily production and contribution to predators peaked from mid July to late September. The annual production to mean biomass $(P / \bar{B})$ ratio, which included the very productive larval stage, was high and ranged from 9.02 to 13.23. Analysis of environmental factors indicated that water temperature and dissolved oxygen were important controllers of growth rate. Inter-annual variability in length-specific mortality was inversely related to mean salinity in the summer and fall, suggesting that salinity controls abundances and spatial distributions of predators on bay anchovy. Results imply that annually variable hydrological conditions and secondary productivity may drive observed variability in recruitment and production of YOY bay anchovy by inducing small but decisive differences in growth and predation mortality on early-life stages.
\end{abstract}

KEY WORDS: Production - Biomass · Mortality - Growth - Bay anchovy · Anchoa mitchilli · Chesapeake Bay

Resale or republication not permitted without written consent of the publisher

\section{INTRODUCTION}

Reliable estimates of production, including stocks of forage fishes that are not exploited by fisheries, are critical to develop multispecies fisheries management plans. Estimating annual production for such stocks, based on physiological and ecological allometric relationships, is a method that has potential and which can be related to environmental variability. Recently, allometric relationships have been applied to address recruitment processes of fish (Pope et al. 1994, Heath 1996, Houde 1996) and to develop biomass sizespectrum models (Kerr \& Dickie 2001). In these approaches, the 2 most important population parameters are size-specific instantaneous mortality $(M)$ and instantaneous (i.e. weight-specific) growth rate $(G)$.
To build upon theory and develop knowledge for eventual application in fish population analysis and fisheries management, size-based approaches could be validated for a wide range of fish species from different ecosystems.

Bay anchovy Anchoa mitchilli is the most abundant fish in Chesapeake Bay and perhaps in nearshore ecosystems along the entire coastline of the eastern USA (Houde \& Zastrow 1991). It feeds on zooplankton, including copepods and other small crustaceans, and is eaten by piscivores, including several economically important fish species. It is an important component in the trophic structure linking zooplankton to piscivores in Chesapeake Bay (Baird \& Ulanowicz 1989, Luo \& Brandt 1993, Hartman \& Brandt 1995). Annual recruitment level of bay anchovy varies approximately 
10-fold (Jung \& Houde 2004). Reliable estimates of consumption, production, and contribution to predator diets are important to evaluate how fluctuating bay anchovy population size may affect the Bay ecosystem through its variable consumption of zooplankton and contribution to diets of predators.

Many aspects of bay anchovy population biology in Chesapeake Bay are well known (Houde \& Zastrow 1991, Newberger \& Houde 1995). Body length rarely exceeds $100 \mathrm{~mm}$ total length (TL). It can survive to $3+\mathrm{yr}$ and reaches approximately $5 \mathrm{~g}$ wet weight (wet wt). Most recruited bay anchovy that survive to maturity are 50 to $65 \mathrm{~mm}$ and weigh 1 to $2 \mathrm{~g}$. Most egg production is by age 1 individuals (Luo \& Musick 1991, Zastrow et al. 1991). Bay anchovy is a batch spawner and spawns repeatedly in Chesapeake Bay from May to September with a peak in July (Luo \& Musick 1991, Zastrow et al. 1991). Individuals are sexually mature 10 to 12 mo after hatching, which corresponds to a fork length of approximately $40 \mathrm{~mm}$ (Zastrow et al. 1991). The small bay anchovy is not a target of directed fisheries.

Research on population dynamics of bay anchovy in Chesapeake Bay includes studies by Rilling \& Houde $(1999 a, b)$, who estimated growth and mortality rates of larvae, and adult (age 1+) biomass from egg production, based on whole-Bay collections in June and July 1993. Newberger \& Houde (1995) estimated parameters of growth and mortality of adult and youngof-the-year (YOY) bay anchovy from samples in midChesapeake Bay during 1986 and 1987. Wang \& Houde (1995) estimated production, based on relative abundance and biomass in the mid-upper Bay in 1990 and 1991. Luo \& Brandt (1993) and Hartman \& Brandt (1995) modeled bay anchovy production and contribution to predators, respectively, in mid-Chesapeake Bay by applying bioenergetics models. Recently, individual-based simulation models were developed (Wang et al. 1997, Cowan et al. 1999, Rose et al. 1999) to estimate probable responses in recruitment, biomass production, and consumption by YOY bay anchovy relative to environmental variability for a small compartment of mid-Chesapeake Bay. None of the earlier research had estimated annual production and its variability for this key species at the baywide scale.

The goal of our research was to evaluate and quantify productivity of bay anchovy in the Chesapeake Bay ecosystem. Objectives were to (1) estimate baywide abundance and biomass of bay anchovy, and their interannual and seasonal variabilities; (2) estimate baywide production, consumption, and contribution to predators by YOY bay anchovy based on growth and mortality rates derived from allometric relationships following an approach suggested by Beyer (1989); and (3) investigate possible mechanisms by which annually variable hydrological conditions could generate observed fluctuations in recruitment and production levels of bay anchovy by altering trophic linkages in Chesapeake Bay.

\section{MATERIALS AND METHODS}

Surveys. Research surveys of the entire Bay were conducted 3 times annually within $5 \mathrm{~d}$ periods (April to May, June to August and October) from 1995 to 2000. Midwater-trawl (MWT) tows were made at 3 or 4 stations per transect in the lower-Bay $\left(37^{\circ} 05^{\prime} \mathrm{N}\right.$ to $\left.37^{\circ} 55^{\prime} \mathrm{N}\right)$, mid-Bay $\left(37^{\circ} 55^{\prime} \mathrm{N}\right.$ to $\left.38^{\circ} 45^{\prime} \mathrm{N}\right)$, and upperBay $\left(38^{\circ} 45^{\prime} \mathrm{N}\right.$ to $39^{\circ} 25^{\prime} \mathrm{N}$ ) (Fig. 1). The number of MWT stations per survey ranged from 24 to 52. Supplementary surveys provided additional data in June 1997, August 1997, 1998, and September 1998.

A MWT with $18 \mathrm{~m}^{2}$ mouth-opening and $3 \mathrm{~mm}$ codend mesh was deployed in standardized tows of 20 min duration from the stern of the $37 \mathrm{~m} \mathrm{RV}$ 'Cape Henlopen'. The trawl was fished in 2 min stepped intervals from surface to bottom to sample the entire water column. Fish catches (or samples) were counted, measured and weighed immediately after a tow. We adjusted trawl catches to account for escapement and size-selective avoidance by anchovies. Procedures to adjust for gear selectivity and estimate adjusted catchper-unit-effort (CPUE) are detailed in Jung (2002) and Jung \& Houde (2004). We expanded the MWT CPUE values to estimate regional abundances and wet weight biomass of bay anchovy $>21 \mathrm{~mm}$ TL by multiplying mean MWT CPUE by $V_{\mathrm{r}} / V_{\mathrm{n}}$, where $V_{\mathrm{r}}$ represents water volume $\left(\mathrm{m}^{3}\right)$ for each of our regions (Cronin 1971) and $V_{\mathrm{n}}$ is the nominal volume sampled by a MWT tow $\left(=989 \mathrm{~m}^{3}\right)$. The baywide volume is: $\Sigma V=$ $V_{\text {lower bay }}+V_{\text {middle bay }}+V_{\text {upper bay }}=26.668+16.840+$ $8.664=52.112\left(\times 10^{9} \mathrm{~m}^{3}\right)$.

Growth and mortality. Equations to estimate growth, mortality, daily abundance, production and contribution to predators of YOY bay anchovy are summarized in Table 1. Compared with past studies, major differences in our research are in methods of estimating mortality and growth of YOY Bay anchovy. We estimated mortality as a function of body size based on the rationale that the total number of eggs produced in a year, which can be estimated from the abundance and fecundity of female spawners in April, should equal the total number of spawned eggs, which can be back-calculated from the abundance of YOY recruits in October and the overall mortality they experienced. Past studies assumed a fixed mortality rate regardless of life stages (Luo \& Brandt 1993, Wang \& Houde 1995) or, even if they adopted an allometric mortality function, did not validate reliability of size-specific mortality (Rose et al. 1999). To estimate 


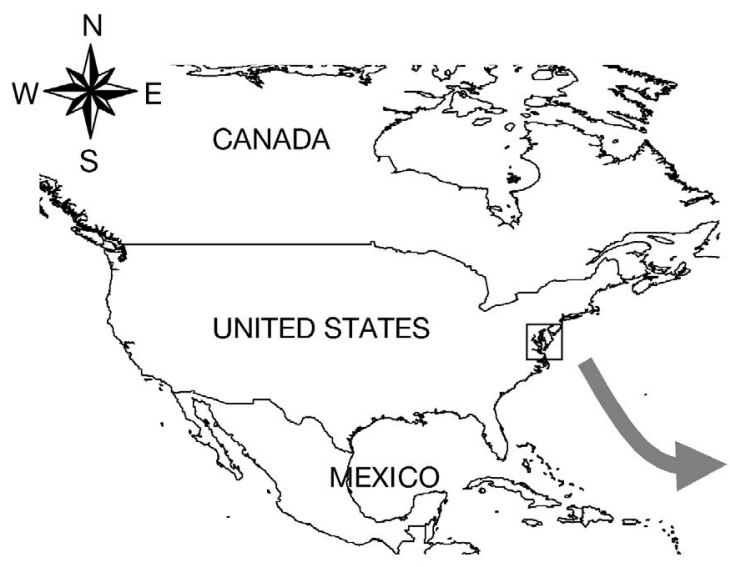

Fig. 1. Chesapeake Bay and mean annually aggregated bay anchovy catch-per-unit-effort (wet wt in g/20 min tow) from 1995 to 2000. Horizontal lines indicate boundaries of the 3 regions

growth, we applied annually variable, allometric growth functions rather than assuming mean growth rates (Wang \& Houde 1995) or applying bioenergetics modeling (Luo \& Brandt 1993, Rose et al. 1999). Despite potential advantages compared to our approach, bioenergetics studies have not evaluated annual variabilities in parameters of bioenergetics models or derived baywide estimates of production for bay anchovy.

Growth and mortality of YOY bay anchovy from egg to juvenile stages, which represent annual averages, were estimated from sequential changes in lengthfrequency distributions. Because of seasonal differences in growth and mortality of YOY bay anchovy, we divided each year into 2 broad periods: 'summer', which was defined as April to October, and 'overwinter', defined as from October to April of the following year. To convert abundance to biomass, the individual wet weights were estimated from a length-weight relationship derived from anchovies collected in each of the cruises (Eq. 1 in Table 1).

Length-frequency distributions of bay anchovy $>21 \mathrm{~mm}$ TL, which approximately corresponds to ages of $>25$ to $35 \mathrm{~d}$, for each survey were constructed for $3 \mathrm{~mm}$ length intervals. The ranges and modal lengths of cohorts of YOY bay anchovy juveniles were determined from the length-frequency distributions, based on assumed normal distributions of cohort abundances with respect to length (Bhattacharya 1967, Jung 2002). Increases in mean length of each cohort over the time intervals in days between 2 consecutive cruises were estimated. Lengths-at-age for the 'summer' period were estimated from fitted von Bertalanffy growth models

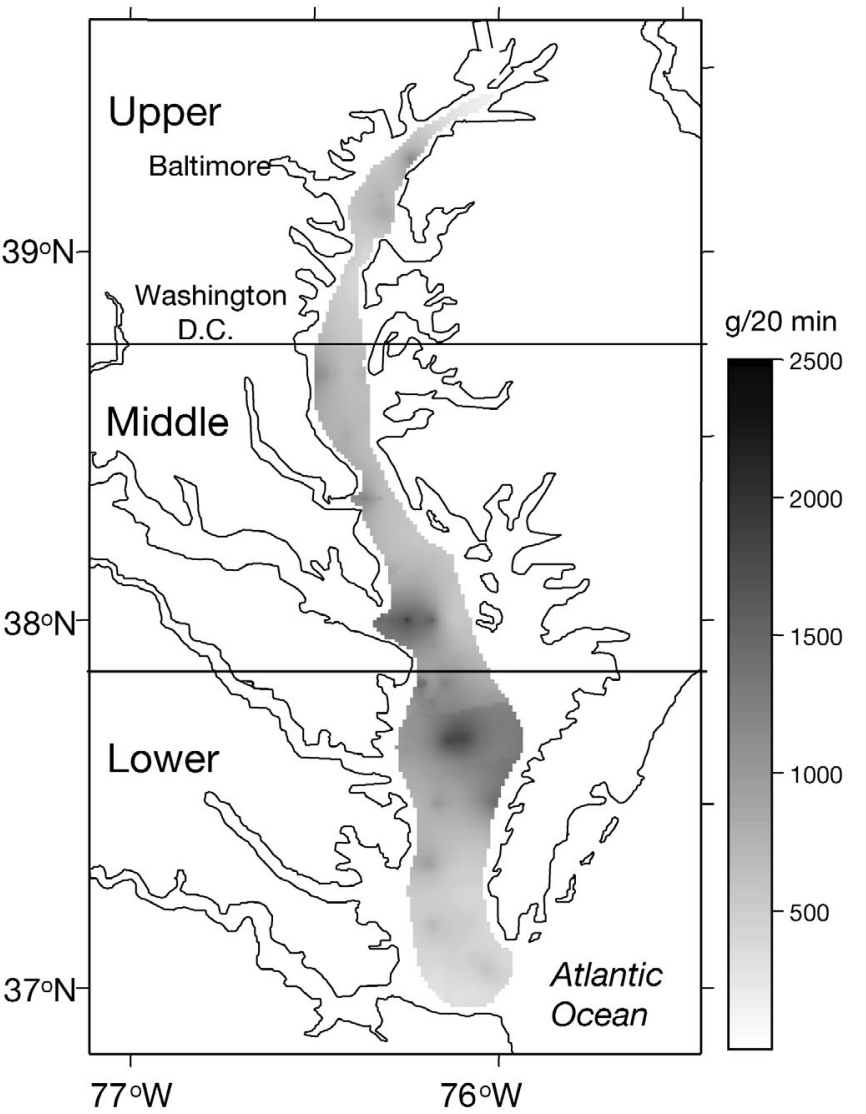

(VBGF) (Eq. 2, see description of variables in Table 1). In Eq. 2, we assigned $L(0)=1.0 \mathrm{~mm}$, the approximate egg size of bay anchovy and assumed that the value of $k$ depends on catabolism and is constant regardless of food supply, but that $L_{\infty}$ is dependent on anabolism and increases with food supply, which in turn is dependent on water temperature (Beverton 1994). In each year, the temperaturedependent function of $L_{\infty}$ (Eq. 3) was fit to our data over the temperature range 18.9 to $22.5^{\circ} \mathrm{C}$. This range represents the annual mean subpycnocline temperature of the lower Bay region between June to August and October. It provided the best fit to Eqs. 2 and 3 when compared with other regional, depth-specific mean temperatures. The lower Bay temperature seemed appropriate because most eggs and larvae of bay anchovy occur in the lower Bay (Auth 2003). An iterative least-squares method (proc NLIN of SAS 6.12; SAS 1989) was applied to estimate the values of $k$ in Eq. 2 and $\alpha$ and $\beta$ in Eq. 3. Auth (2003) fit a Gompertz growth model for larval-stage bay anchovy in Chesapeake Bay for each year in 1995 to 1999 (Eq. 4). This growth relationship for larval stages (2 to $24 \mathrm{~mm}$ standard length, SL) was applied during the initial stage of the iterative least-squares procedure. 
Table 1. Equations used to estimate growth, mortality and production of young-of-the-year bay anchovy in Chesapeake Bay

\begin{tabular}{|c|c|c|c|c|}
\hline & Equation & Variable & Variable description (unit) & $\begin{array}{l}\text { Equation } \\
\text { description }\end{array}$ \\
\hline (1) & $\mathrm{w}=a \cdot L^{3}$ & $\begin{array}{l}\mathrm{W} \\
L \\
a\end{array}$ & $\begin{array}{l}\text { Wet weight }(\mathrm{g}) \\
\text { Total length }(\mathrm{mm}) \\
\text { Constant that is specific for each survey period }\end{array}$ & $\begin{array}{l}\text { Length-weight } \\
\text { relationship }\end{array}$ \\
\hline$(2)$ & $\begin{array}{l}L(t)=L_{\infty}\left\{1-\exp \left[-k\left(t-t_{0}\right)\right]\right\} \text { or } \\
t=-\log _{\mathrm{e}}\left\{1-\left[L(t) / L_{\infty}\right]\right\} / k+t_{0}\end{array}$ & $\begin{array}{l}L(t) \\
t \\
L_{\infty} \\
k \\
t_{0}\end{array}$ & $\begin{array}{l}\text { Total length }(\mathrm{mm}) \text { at age } t \\
\text { Age }(\mathrm{d}) \\
\text { Mean asymptotic length ( } \mathrm{mm} \text { ) of YOY bay anchovy } \\
\text { for the summer period } \\
\text { Growth coefficient } \\
\text { Theoretical age (d) at which an anchovy would have } \\
\text { been zero length }\end{array}$ & 'Summer' growth \\
\hline (3) & $L_{\infty}=\beta \exp (\alpha \cdot T)$ & $\begin{array}{l}\alpha \text { and } \beta \\
T\end{array}$ & $\begin{array}{l}\text { Constants } \\
\text { Mean subpycnocline temperature }\left({ }^{\circ} \mathrm{C}\right) \text { of the lower } \\
\text { Bay region between June-August and October for } \\
\text { each year }\end{array}$ & $\begin{array}{l}\text { Temperature- } \\
\text { dependent } \\
\text { asymptotic length }\end{array}$ \\
\hline (4) & $L_{\mathrm{s}}(t)=24.1899 \exp \{-2.7449[\exp (-0.102 \cdot t)]\}$ & $L_{\mathrm{s}}(t)$ & Standard length $(\mathrm{mm})$ at age $t$ days & $\begin{array}{l}\text { Larval growth } \\
\text { (Auth 2003) }\end{array}$ \\
\hline (5) & $\begin{array}{l}L(t)=[\text { summer growth }]+[\text { overwinter growth }] \\
=L_{\infty}\left\{1-\exp \left[-k\left(t_{c}-t_{0}\right)\right]\right\}+L_{\infty}^{\prime}\left\{1-\exp \left[-k\left(t-t_{c}\right)\right]\right\}\end{array}$ & $\begin{array}{l}L_{\infty}^{\prime} \\
t_{\mathrm{c}}\end{array}$ & $\begin{array}{l}\text { Asymptotic increase in length }(\mathrm{mm}) \text { of age } 0 \text { bay } \\
\text { anchovy during the 'overwinter' period } \\
\text { Age (d) of an anchovy during the October survey }\end{array}$ & $\begin{array}{l}\text { 'Overwinter' } \\
\text { growth }\end{array}$ \\
\hline (6) & $M(L)=q L^{-1}$ & $\begin{array}{l}M(L) \\
q\end{array}$ & $\begin{array}{l}\text { Length-specific mortality } \\
\text { A parameter defining length-specific }\left(\mathrm{mm}^{-1}\right) \text {, but } \\
\text { annually variable, mortality }\end{array}$ & $\begin{array}{l}\text { Instantaneous } \\
\text { mortality during } \\
\text { 'summer' period }\end{array}$ \\
\hline (7) & $M(L)=C$ & C & Constant & $\begin{array}{l}\text { Instantaneous } \\
\text { mortality during } \\
\text { 'overwinter' period }\end{array}$ \\
\hline \multirow[t]{3}{*}{ (8) } & $N_{0}=\sum_{l=1}^{27} N_{l}\left(304.79+421.84 \cdot W_{l}\right) \cdot 55 \cdot 1 / 2$ & $N_{l}$ & $\begin{array}{l}\text { Abundance of bay anchovy in a length class, } 1 \text {, in } \\
\text { April-May (spawners) }\end{array}$ & $\begin{array}{l}\text { Total fecundity of } \\
\text { spawners }\left(N_{0}\right)\end{array}$ \\
\hline & & $\begin{array}{l}1 \\
w_{1} \\
55\end{array}$ & $\begin{array}{l}\text { Length-class of spawners } \\
\text { Mean wet weight of the length class, } 1 \\
\text { Average annual number of spawnings per female } \\
\text { (Luo \& Musick 1991) }\end{array}$ & \\
\hline & & $1 / 2$ & The 1:1 sex ratio (Newberger \& Houde 1995) & \\
\hline \multirow[t]{4}{*}{ (9) } & $N(i, 0)=N\left(i, t_{\mathrm{c}}\right) \exp \sum_{j=0}^{t_{\mathrm{c}}} q L(i, j)_{j}^{-1}$ & $N(i, 0)$ & $\begin{array}{l}\text { Back-calculated initial number of eggs leading to a } \\
\text { YOY length class } i \text { during the October cruise }\end{array}$ & $\begin{array}{l}\text { Back-calculated } \\
\text { initial number of }\end{array}$ \\
\hline & & $N\left(i, t_{c}\right)$ & $\begin{array}{l}\text { Baywide abundance of the YOY bay anchovy length } \\
\text { class } i \text { whose age was } t_{c} \text { days during the October } \\
\text { cruise }\end{array}$ & $\begin{array}{l}\text { eggs for a YOY } \\
\text { length class }\end{array}$ \\
\hline & & $i$ & $\begin{array}{l}\text { Each length class in the October length frequency } \\
\text { distribution of YOY bay anchovy }(i=1,2,3, \ldots, 27 \\
\text { corresponding to the median lengths } 21,24,27, \ldots \\
99 \mathrm{~mm} \text { TL) }\end{array}$ & \\
\hline & & $\begin{array}{l}j \\
t_{\mathrm{c}} \\
L(i, j)_{j} \\
\sum_{j=0}^{t_{\mathrm{c}}} q L(i, j)^{-1}\end{array}$ & $\begin{array}{l}\text { Number of days (d) after being spawned } \\
\text { Age of a length class during the October cruise } \\
\text { Total length }(\mathrm{mm}) \text { of the } i \text {-th length class at age }=j \\
\text { days (Eq. } 2 \text { ) } \\
\text { Cumulative mortality of the length class } i \text { from } \\
\text { age }=0 \text { (egg) to } t_{\mathrm{c}} \text { days }\end{array}$ & \\
\hline$(10)$ & $N_{0}=\sum_{i=1}^{\max _{i}}[N(i, 0)]$ & $\max _{i}$ & Largest length-class of YOY bay anchovy in October & $\begin{array}{l}\text { Back-calculated } \\
\text { initial number of } \\
\text { eggs for all YOY } \\
\text { length classes }\end{array}$ \\
\hline (11) & $N(i, t)=N(i, 0) \exp \left[-\sum_{j=0}^{t} q L(i, j)^{-1}\right]$ & $N(i, t)$ & $\begin{array}{l}\text { Abundance of the } i \text {-th length class at } t \text { days after } \\
\text { birth }\end{array}$ & $\begin{array}{l}\text { Generalized back- } \\
\text { calculated abun- } \\
\text { dance of YOY bay } \\
\text { anchovy }\end{array}$ \\
\hline
\end{tabular}


Table 1 (continued)

\begin{tabular}{|c|c|c|c|c|}
\hline & Equation & Variable & Variable description (unit) & $\begin{array}{l}\text { Equation } \\
\text { description }\end{array}$ \\
\hline$(12)$ & $B(d)=\sum_{i=1}^{\max _{i}} B(i, d)=\sum_{i=1}^{\max _{i}} N(i, d) w(i, d)$ & $\begin{array}{l}B(i, d) \\
d\end{array}$ & $\begin{array}{l}\text { Biomass }(g) \text { of the } i \text {-th length class on Day } d \\
\text { Number of days (d) since April } 15\end{array}$ & $\begin{array}{l}\text { Biomass of YOY } \\
\text { bay anchovy }\end{array}$ \\
\hline (13) & $\bar{B}=\sum_{d=1}^{365} B(d) / 365$ & $\bar{B}$ & & $\begin{array}{l}\text { Annual mean } \\
\text { biomass of YOY } \\
\text { bay anchovy }\end{array}$ \\
\hline \multirow{3}{*}{ (14) } & $C(d)=\sum_{i=1}^{\max _{i}} C(i, d)=$ & $C(i, d)$ & $\begin{array}{l}\text { Daily contribution (g) to predators of the } i \text {-th length } \\
\text { class on Day } d\end{array}$ & \multirow{4}{*}{$\begin{array}{l}\text { Contribution to } \\
\text { predators by } \\
\text { YOY bay } \\
\text { anchovy }\end{array}$} \\
\hline & \multirow{2}{*}{$\sum_{i=1}^{\max _{i}} \frac{w(i, t)+w(i, t+1)}{2} N_{l, d}\{1-\exp [-M(i, d)]\}$} & $C(d)$ & $\begin{array}{l}\text { Daily contribution }(\mathrm{g}) \text { to predators of YOY bay } \\
\text { anchovy }\end{array}$ & \\
\hline & & $M(i, d)$ & $\begin{array}{l}\text { Instantaneous mortality of the } i \text {-th length-class on } \\
\text { Day } d \text { (Eqs. } 6 \text { \& } 7 \text { ) }\end{array}$ & \\
\hline$(15)$ & $C_{\text {total }}=\sum C(d)$ & $C_{\text {total }}$ & $\begin{array}{l}\text { Annual contribution to predators (in weight) by YOY } \\
\text { anchovy }(\mathrm{g})\end{array}$ & \\
\hline$(16)$ & $P(d)=\sum_{i=1}^{\max _{i}} P(i, d)=$ & $\begin{array}{l}P(i, d) \\
P(d)\end{array}$ & $\begin{array}{l}\text { Daily production }(\mathrm{g}) \text { of the } i \text {-th length class on Day } d \\
\text { Daily production of YOY bay anchovy }(\mathrm{g})\end{array}$ & \multirow{3}{*}{$\begin{array}{l}\text { Production of } \\
\text { YOY bay } \\
\text { anchovy }\end{array}$} \\
\hline & $\sum_{i=1}^{\max _{i}} B(i, d)-B(i, d-1)+C(d)$ & & & \\
\hline (17) & $P_{\text {total }}=\sum P(d)$ & $P_{\text {total }}$ & Annual production of YOY anchovy (g) & \\
\hline
\end{tabular}

Additional VBGF models were developed to estimate growth in the overwinter period (Eq. 5). Because winter water temperatures were not measured, the values of $L_{\infty}^{\prime}$ were estimated directly by an iterative least-squares procedure minimizing overall differences between the observed and expected length frequencies in April to May based on the previous October length frequencies.

Based on previous studies (Houde 1997), we were aware that the instantaneous mortalities of bay anchovy in Chesapeake Bay decreased with body size from egg to juvenile stages. Reported instantaneous mortalities were fit well by the allometric relationship proposed by Beyer (1989) (Eq. 6). The value of $q$, length-specific mortality, was unknown and we estimated it for each year by the method explained below under 'Daily cohort abundances'.

For the overwinter period, a preliminary analysis indicated that mortality rate did not differ significantly with respect to anchovy body size. Therefore, we assumed $M$ in Eq. 7 to be annually variable during the overwinter period but constant with respect to body size (Eq. 7). The value of $C$ in Eq. 7 was estimated for each year from the 'overwinter' cumulative mortality defined by the difference in total abundance of YOY bay anchovy between October and the following April.

Daily cohort abundances. Daily abundances of a length group $i$, each of which was represented by length classes in the October length-frequency distrib- utions, were estimated based on (1) the October length frequencies; (2) growth and growth-dependent mortality of YOY bay anchovy (Eqs. 2 and 6 in Table 1); and (3) the total number of eggs produced from estimated spawner fecundity (Eqs. 8 to 11 in Table 1). The principle adopted to estimate the mortality parameter $q$ is that the total number of spawned eggs estimated from the October YOY length frequencies and their estimated cohort mortalities (back-calculated estimate, Eqs, 9 and 10) will equal the total number of eggs produced based on reported fecundity of female spawners (Zastrow et al. 1991) and their abundance during the spawning season (Eq. 8). Then, the value of $q$ that satisfies the following equation was determined by an iterative least squares method:

$$
\begin{aligned}
\sum_{i=1}^{\max _{i}}\left\{N\left(i, t_{\mathrm{c}}\right) \exp \left[\sum_{j=0}^{t_{\mathrm{c}}} q L_{i}(j)^{-1}\right]\right\}= \\
\sum_{l=1}^{27} N_{l}\left(304.79+421.84 \cdot w_{l}\right) \cdot 55 \cdot 1 / 2
\end{aligned}
$$

Based on the estimated values of $q$ and the initial egg number corresponding to each cohort, daily cohort abundances were estimated (Eq. 11). Daily biomass, production and contribution to predators.

Daily standing stock biomass was estimated by summing the biomasses of each length class (Eq. 12, Table 1). In Eq. 12, we defined April 15 as the starting date $(d=1)$, because no anchovy eggs are produced 
Table 2. Baywide abundances, mean lengths, and back-calculated mean birth dates of young-of-the-year (YOY) bay anchovy cohorts from 1995 to 2000 in Chesapeake Bay. Cohorts 1, 2, 3 and 4 represents YOY bay anchovy > $21 \mathrm{~mm}$ TL

\begin{tabular}{|c|c|c|c|c|c|c|c|c|c|c|c|c|c|c|c|c|}
\hline \multirow{3}{*}{$\begin{array}{l}\text { Cruise } \\
\text { (departure } \\
\text { date) } \\
(\mathrm{mo} / \mathrm{d} / \mathrm{yr})\end{array}$} & \multirow{3}{*}{$\begin{array}{l}- \\
1\end{array}$} & \multicolumn{4}{|c|}{ Mean total length (mm) } & \multirow{2}{*}{\multicolumn{4}{|c|}{$\begin{array}{c}\text { Back-calculated mean birth } \\
\text { date (mo/d) } \\
\text { YOY cohort no. }\end{array}$}} & \multirow{2}{*}{\multicolumn{4}{|c|}{$\begin{array}{l}\text { Abundance } \\
\left(\times 10^{9}\right) \\
\text { YOY cohort no. }\end{array}$}} & \multirow{3}{*}{ Adult } & \multirow{3}{*}{$\overline{\text { Sum }}$} & \multirow{3}{*}{$\begin{array}{l}\text { Density of } \\
\text { YOY + adult } \\
\quad\left(\text { no. } \mathrm{m}^{-3}\right)\end{array}$} \\
\hline & & \multicolumn{3}{|c|}{ YOY cohort no. } & \multirow[t]{2}{*}{ Adult } & & & & & & & & & & & \\
\hline & & 2 & 3 & 4 & & 1 & 2 & 3 & 4 & 1 & 2 & 3 & 4 & & & \\
\hline 04/27/95 & & & & & 60.2 & & & & & & & & & 2.1 & 2.1 & 0.04 \\
\hline 07/22/95 & 40.8 & 28.5 & & & 70.8 & & & & & 42.7 & 25.4 & & & 3.6 & 71.8 & 1.38 \\
\hline $10 / 28 / 95$ & 62.1 & 53.4 & 42.0 & 24.0 & 71.5 & 07/11 & $08 / 09$ & 09/04 & $10 / 02$ & 24.2 & 10.6 & 9.5 & 0.2 & 3.2 & 47.7 & 0.92 \\
\hline $04 / 27 / 96$ & & & & & 65.8 & & & & & & & & & 4.9 & 4.9 & 0.09 \\
\hline 07/16/96 & 30.2 & & & & 64.1 & & & & & 8.0 & & & & 1.2 & 9.2 & 0.18 \\
\hline $10 / 22 / 96$ & 64.5 & 56.6 & 40.1 & & 72.7 & $05 / 13$ & $07 / 02$ & $08 / 24$ & & 2.2 & 12.6 & 14.4 & & 2.3 & 31.5 & 0.60 \\
\hline 04/20/97 & & & & & 64.3 & & & & & & & & & 11.8 & 11.8 & 0.23 \\
\hline 07/11/97 & 24.3 & & & & 67.0 & & & & & 0.1 & & & & 9.4 & 9.5 & 0.18 \\
\hline 08/02/97 & 36.3 & & & & 67.3 & & & & & 15.1 & & & & 9.9 & 24.9 & 0.48 \\
\hline $10 / 29 / 97$ & 60.2 & 52.3 & 42.1 & & 71.7 & $06 / 23$ & $07 / 28$ & $08 / 27$ & & 17.1 & 53.9 & 26.0 & & 3.0 & 100.1 & 1.92 \\
\hline $04 / 11 / 98$ & & & & & 63.4 & & & & & & & & & 3.6 & 3.6 & 0.07 \\
\hline 07/18/98 & 24.0 & & & & 67.7 & & & & & 0.1 & & & & 8.6 & 8.6 & 0.17 \\
\hline $08 / 03 / 98^{a}$ & 52.5 & 39.1 & 25.1 & & 64.1 & & & & & 1.0 & 6.3 & 26.6 & & 6.5 & 40.5 & 0.78 \\
\hline 09/06/98 & 60.0 & 55.7 & 39.6 & 23.0 & 68.1 & & & & & 2.4 & 5.9 & 92.6 & 321.4 & 3.5 & 425.8 & 8.17 \\
\hline $10 / 18 / 98$ & 69.0 & 64.7 & 55.2 & 43.0 & 74.7 & $05 / 28$ & $06 / 20$ & $07 / 25$ & $08 / 24$ & 2.1 & 9.0 & 62.1 & 200.6 & 3.0 & 276.8 & 5.31 \\
\hline 04/18/99 & & & & & 61.2 & & & & & & & & & 6.9 & 6.9 & 0.13 \\
\hline $06 / 25 / 99$ & & & & & 66.3 & & & & & & & & & 5.5 & 5.5 & 0.11 \\
\hline $07 / 13 / 99^{a}$ & 32.6 & & & & 64.2 & & & & & 6.6 & & & & 16.9 & 23.5 & 0.45 \\
\hline $10 / 23 / 99$ & 54.0 & 36.8 & & & 65.5 & 07/06 & $08 / 29$ & & & 83.9 & 15.5 & & & 26.5 & 125.9 & 2.42 \\
\hline $04 / 28 / 00$ & & & & & 68.4 & & & & & & & & & 6.2 & 6.2 & 0.12 \\
\hline $07 / 25 / 00$ & 39.2 & 28.7 & & & 67.3 & & & & & 102.9 & 109.7 & & & 2.5 & 215.1 & 4.13 \\
\hline $10 / 17 / 00$ & 59.4 & 51.9 & 39.2 & 25.6 & 74.8 & $06 / 29$ & $07 / 26$ & $08 / 25$ & 09/17 & 79.7 & 44.3 & 42.1 & 16.7 & 2.0 & 184.7 & 3.54 \\
\hline
\end{tabular}

before this date. To estimate $N(i, d)$ and $w(i, d)$ in Eq. 12, based on Eqs. 1, 2 and 11, Day $d$ must be converted to a corresponding age $t=t_{C}-$ (October cruise date $)+($ April 15) $+d$. Annual mean biomass of YOY bay anchovy was estimated by dividing the sum of daily biomass by 365 d (Eq. 13). Since defined length classes in October were discontinuous (cohorts defined by $3 \mathrm{~mm}$ classes), the back-calculated daily egg pro-

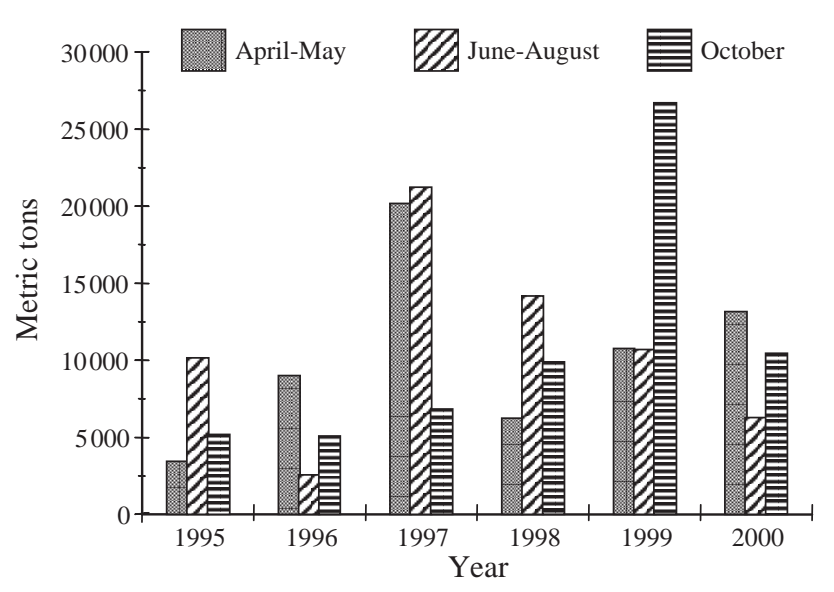

Fig. 2. Baywide spawning stock biomass of bay anchovy in Chesapeake Bay from 1995 to 2000 ductions estimated by Eq. 10 also were discontinuous. To report egg productions that corresponded to the original $1 \mathrm{~mm}$ interval length distributions of YOY anchovy, we assumed that change in YOY daily biomass is smooth and continuous. We then estimated the date of peak spawning activity after applying a modified, moving-average smoothing in which the moving average of YOY daily biomass is calculated both for the previous $15 \mathrm{~d}$ and the next $15 \mathrm{~d}$.

Daily and annual baywide contribution to predators of YOY bay anchovy was estimated by multiplying the YOY standing stock biomass by daily instantaneous mortality, assuming that all mortality is from predation (Eqs. 14 and 15). Then, daily and annual production of YOY bay anchovy was estimated from a mass balance relationship (Eqs. 16 and 17), i.e. (current Biomass) = (previous Biomass) + (Production) - (Contribution to predators). Linear regressions indicated that estimates of mean biomass, production, and contribution to predators by YOY bay anchovy during the overwinter period (October to April) were mostly determined by the number of age 0 recruits in October from 1995 to 1999 (for each of the dependent variables, $\mathrm{r}^{2}>0.98$, $\mathrm{p}<0.0005, \mathrm{~N}=5$ ). These linear regressions were applied to predict the 2000 to 2001 overwinter estimates of mean biomass, production, and contribution 
Table 3. Estimated parameters of the von Bertalanffy growth model (VBGF) (see Eqs. 2 to 5) for young-of-the-year (YOY) bay anchovy in Chesapeake Bay from 1995 to 2000, and the mean growth rates in wet wt ( $\mathrm{g} \mathrm{d}^{-1}$ ) or total length (mm/day) for the larval stage ( 0 to $35 \mathrm{~d}$ age), YOY for the summer period (0 to $180 \mathrm{~d}$ age) and YOY for the winter period (from 0 to $180 \mathrm{~d}$ after October cruise). The von Bertalanffy growth coefficient, $k=0.0134$. CV: coefficient of variation (\%). n/a: final research cruise was in

October 2000 and estimated parameters for the 2000 to 2001 overwinter growth are not available

\begin{tabular}{|c|c|c|c|c|c|c|c|c|c|}
\hline \multirow{3}{*}{ Year } & \multirow{3}{*}{$T\left({ }^{\circ} \mathrm{C}\right)$} & \multicolumn{3}{|c|}{ Parameters of VBGF } & \multicolumn{5}{|c|}{ - Mean growth rate } \\
\hline & & $L_{\infty}$ & $L_{\infty}^{\prime}$ & $t_{0}$ & \multirow{2}{*}{$\begin{array}{c}\text { Larva } \\
\left(\mathrm{mm} \mathrm{d}^{-1}\right)\end{array}$} & \multicolumn{2}{|c|}{ Summer } & \multicolumn{2}{|c|}{ Winter } \\
\hline & & & & & & $\left(\mathrm{mm} \mathrm{d}^{-1}\right)$ & $\left(\mathrm{g} \mathrm{d}^{-1}\right)$ & $\left(\mathrm{mm} \mathrm{d}^{-1}\right)$ & $\left(\mathrm{g} \mathrm{d}^{-1}\right)$ \\
\hline 1995 & 22.5 & 80.7 & 8.3 & -0.9 & 0.85 & 0.40 & 0.0137 & 0.04 & 0.0031 \\
\hline 1996 & 19.8 & 72.7 & 11.6 & -1.0 & 0.77 & 0.36 & 0.0105 & 0.06 & 0.0039 \\
\hline 1997 & 20.0 & 73.2 & 11.9 & -1.0 & 0.77 & 0.37 & 0.0110 & 0.06 & 0.0043 \\
\hline 1998 & 22.4 & 80.6 & 14.8 & -0.9 & 0.85 & 0.40 & 0.0142 & 0.07 & 0.0051 \\
\hline 1999 & 18.9 & 70.2 & 14.7 & -1.1 & 0.74 & 0.35 & 0.0092 & 0.07 & 0.0057 \\
\hline 2000 & 21.3 & 77.0 & $\mathrm{n} / \mathrm{a}$ & -1.0 & 0.81 & 0.38 & 0.0122 & $\mathrm{n} / \mathrm{a}$ & $\mathrm{n} / \mathrm{a}$ \\
\hline Mean & 20.8 & 75.7 & 12.3 & -1.0 & 0.80 & 0.38 & 0.0118 & 0.06 & 0.0044 \\
\hline CV & 7.0 & 5.8 & 21.8 & 5.9 & 5.9 & 5.9 & 16.3 & 21.8 & 23.2 \\
\hline
\end{tabular}

to predators for which we had no direct estimates of growth and mortality rate (final research cruise was in October 2000).

Environmental factors: correlation analyses. Correlation analyses were conducted to examine bay anchovy spawning date, survival, growth, and production in relation to environmental and biological factors for the summer period, when most YOY production occurs. Regional- and depth-specific (above and below pycnocline) mean temperature, salinity and dissolved oxygen (DO) were environmental variables included in the analysis.

\section{RESULTS}

\section{Abundance, biomass and egg production}

The annual recruitment levels (baywide abundance of YOY bay anchovy $>21 \mathrm{~mm}$ TL in October) varied 9-fold (Table 2). Recruitments increased after 1996 and, on average, were 4 times higher in 1997 to 2000 $\left(97\right.$ to $\left.274 \times 10^{9}\right)$ than in 1995 to $1996\left(29\right.$ to $\left.\sim 45 \times 10^{9}\right)$. Seasonally, baywide abundance of YOY and adult anchovy generally increased from April to October (Table 2), and peaked from late July to October. The baywide spawning stock (adult male + female) biomass in April to May varied 6-fold among years (Fig. 2). It was highest in 1997 (20100 t) and lowest in 1995 (3300 t). In the April to May to June to August period, estimated spawning stock biomass (SSB) increased in 1995 and 1998, decreased in 1996 and 2000, and was stable in 1997 and 1999. In the June-August to October period, estimated baywide SSB decreased considerably in 1995, 1997, and 1998, but increased in other years. Back-calculated birth dates of recruiting YOY cohorts, derived from their estimated growth rates, indicated that bay anchovy recruits were hatched from early May to early October (Table 2).

\section{Growth}

The modal analyses of lengths in October separated recruiting YOY anchovy into 2 to 4 cohorts in 1995 to 2000 (Table 2). YOY bay anchovy were assigned to 3 cohorts in 1996 and 1997, 4 cohorts in 1995, 1998 and 2000, and 2 cohorts in 1999.

The iterative least-squares procedure, which was used to fit the 'summer' von Bertalanffy-modeled growth (VBGF, Eqs. 2 and 3), estimated that $\alpha=0.040$, $\beta=33$ and $k=0.0134$. Because we modeled $L_{\infty}$ in relation to water temperature (Eq. 3), the VBGF varied among years mostly in response to subpycnocline mean temperature in the lower Bay between June to August and October (Table 3, Fig. 3). The 'summer' annual growth-in-weight rates of YOY anchovies, averaged for the 0 to $180 \mathrm{~d}$ postspawn period, ranged from 0.0092 (1999) to 0.0142 (1998) $\mathrm{g} \mathrm{d}^{-1}$ (Table 3). Estimated values of $a$ in the length-weight relationship (Eq. 1) ranged from exp $(-12.084)$ in October 2000 to $\exp (-11.779)$ in July 1996, implying that, at an equal

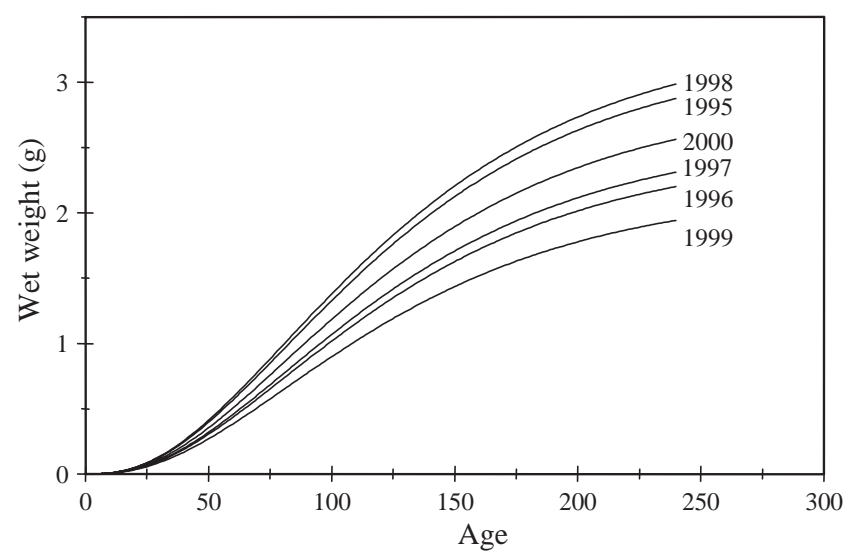

Fig. 3. Growth-in-weight trajectories of young-of-the-year (YOY) bay anchovy in Chesapeake Bay based on fitted von Bertalanffy growth models for the years 1995 to 2000 
Table 4. Baywide estimates of egg production, length-specific mortality $(q)^{\text {a }}$, and recruitment of bay anchovy in Chesapeake Bay for the years 1995 to 2000. M: instantaneous mortality $\left(\mathrm{d}^{-1}\right) ; M_{\text {cum }}$ : cumulative mortality; CV: coefficient of variation (\%). n/a: final research cruise was in October 2000 and estimated parameters for the 2000 to 2001 overwinter growth are not available

\begin{tabular}{|c|c|c|c|c|c|c|c|c|c|}
\hline $\begin{array}{r}\text { Year } \\
\text { al } \\
\text { ad }\end{array}$ & $\begin{array}{c}\text { Baywide } \\
\text { abundance of } \\
\text { adults in April- } \\
\text { May }\left(\times 10^{9}\right)\end{array}$ & $\begin{array}{l}\text { Total egg } \\
\text { production } \\
\left(\times 10^{14}\right)\end{array}$ & $\begin{array}{c}q \\
\text { April- } \\
\text { October }\end{array}$ & $\begin{array}{c}M_{\text {cum }} \\
\text { April- } \\
\text { October }\end{array}$ & $\begin{array}{l}\text { Back-calculated } \\
\text { date of } \\
\text { maximum } \\
\text { spawning }\end{array}$ & $\begin{array}{c}\text { Number of } \\
\text { recruits in } \\
\text { October } \\
\left(\times 10^{9}\right)\end{array}$ & $\begin{array}{l}\text { Mean } M \\
\left(\mathrm{~d}^{-1}\right) \\
\text { October- } \\
\text { April }\end{array}$ & $\begin{array}{l}M_{\text {cum }} \\
\text { October- } \\
\text { April }\end{array}$ & $\begin{array}{c}M_{\text {cum }} \\
\text { for a year }\end{array}$ \\
\hline 1995 & 2.1 & 0.6 & 1.29 & 7.1 & $07 / 15$ & 44.5 & 0.012 & 2.3 & 9.4 \\
\hline 1996 & 4.9 & 1.5 & 1.43 & 8.5 & $06 / 29$ & 29.2 & 0.005 & 1.0 & 9.5 \\
\hline 1997 & 11.8 & 3.4 & 1.36 & 8.2 & $07 / 10$ & 97.0 & 0.020 & 3.3 & 11.5 \\
\hline 1998 & 3.6 & 1.0 & 1.17 & 5.9 & 08/01 & 273.8 & 0.020 & 3.7 & 9.6 \\
\hline 1999 & 6.9 & 1.8 & 1.18 & 7.5 & $06 / 22$ & 99.4 & 0.016 & 3.0 & 10.5 \\
\hline 2000 & 6.2 & 2.1 & 1.25 & 7.0 & $07 / 04$ & 182.7 & $\mathrm{n} / \mathrm{a}$ & $\mathrm{n} / \mathrm{a}$ & $\mathrm{n} / \mathrm{a}$ \\
\hline Mean & 5.9 & 1.7 & 1.28 & 7.4 & $07 / 08$ & 121.1 & 0.015 & 2.7 & 10.1 \\
\hline CV 57.1 & 57.4 & 8.0 & 12.5 & & 76.1 & 41.9 & 40.5 & 8.9 & \\
\hline
\end{tabular}
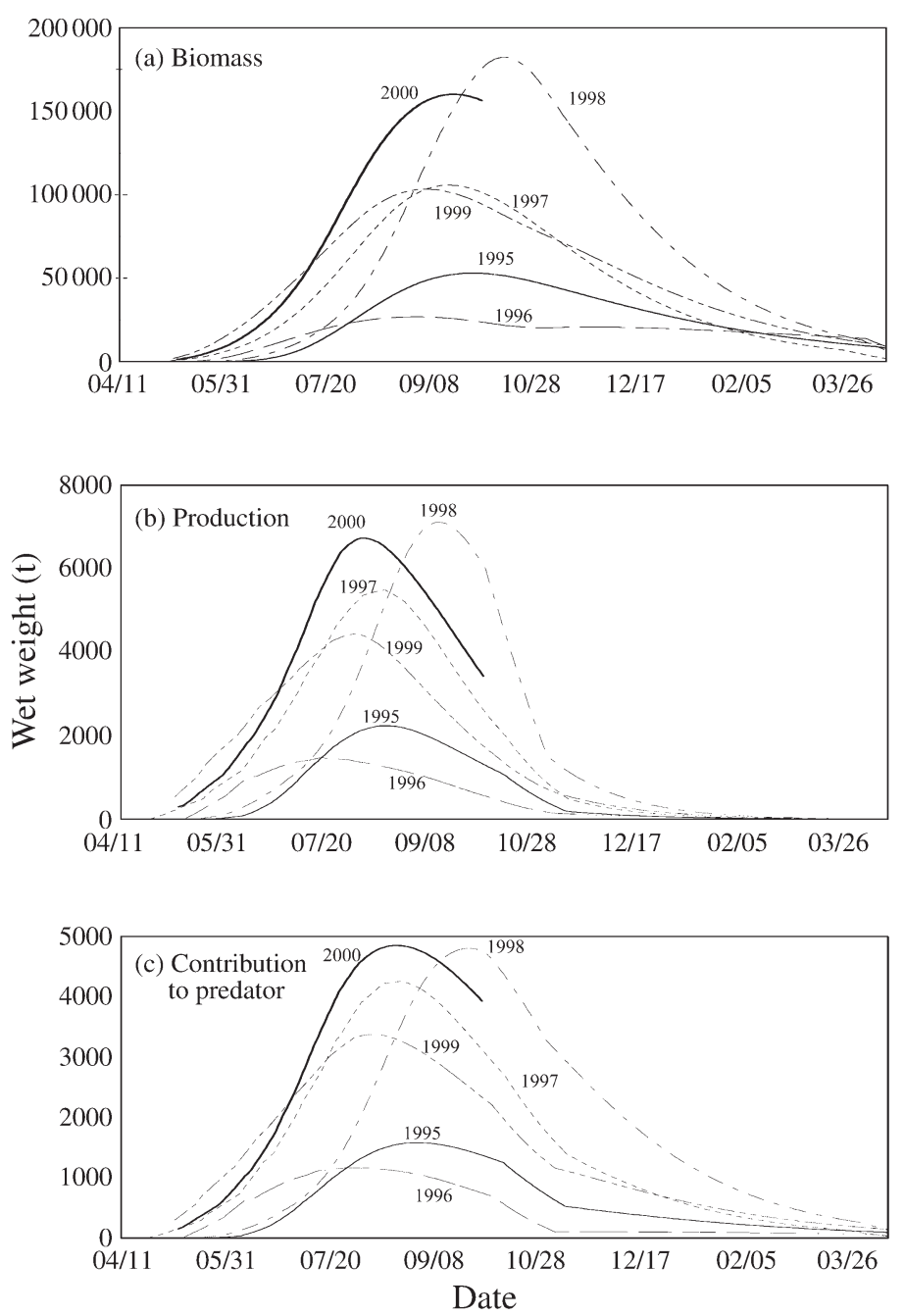

Fig. 4. Back-calculated (a) standing stock biomass, (b) daily production and (c) daily contribution to predators of young-ofthe-year bay anchovy in Chesapeake Bay from April of the present year to April of the following year, 1995 to 2000. Dates are $\mathrm{mo} / \mathrm{d}$ length, corresponding wet wt was $36 \%$ higher in July 1996 than in October 2000. Based on growth rates, the 6 years could be divided arbitrarily into 3 groups: fast growth years (1995, 1998 and 2000), moderate growth years (1996 and 1997), and a slow growth year (1999). There were 4 identified YOY cohorts in the years with fast growth rates, whereas there were only 2 YOY cohorts in the slow growth year and 3 in the moderate growth years (Table 2). Mean temperature from June-August to October in the subpycnocline layer of the lower Bay was highest in 1995 and 1998 (high growth year) and lowest in 1999 (low growth year).

The overwinter (October to April) growth rates (Eq. 5, Table 3) in wet wt were lower, but differed annually $(\mathrm{CV}=23.2 \%)$. The estimated overwinter growth-in-weight rates increased each year from 1995 to $1996\left(0.0031 \mathrm{~g} \mathrm{~d}^{-1}\right)$ to 1999 to $2000\left(0.0057 \mathrm{~g} \mathrm{~d}^{-1}\right)$.

\section{Mortality}

Estimated total number of eggs produced during the spawning season, based on Eqs. 9 and 10, ranged from $0.6 \times 10^{14}$ in 1995 to $3.4 \times 10^{14}$ in 1997 , and averaged $1.7 \times 10^{14}$ (Table 4$)$. The estimated size-specific instantaneous mortality ( $q$ in Eqs. 6 and 9) for YOY bay anchovy from April to October ranged from 1.17 in 1998 to 1.43 in $1996($ mean $=1.28 \pm 0.04$; Table 4$)$. The estimated instantaneous overwinter mortality from October to April (Eq. 7) varied markedly and differed among years by a factor of 3.7, ranging from $0.005 \mathrm{~d}^{-1}$ in 1996 to 1997 to $0.020 \mathrm{~d}^{-1}$ in 1997 to 1998 and 1998 to 1999. Although summer cumulative mortality varied annually only by a factor of 1.4, this difference and differences in annual egg production were sufficient to generate 9.4-fold variability in recruitment levels in October (Table 4). Estimated cumulative mortality 
from April to October was highest in 1996, but overwinter mortality from October 1996 to April 1997 was the lowest in the series.

\section{Biomass, production, contribution to predators by YOY bay anchovy}

Back-calculated daily biomass $(B)$ of YOY bay anchovy increased steadily from May to the early September to mid-October period and decreased thereafter (Fig. 4a). Annual mean $B(\bar{B})$ of YOY anchovy was highest in 1998 and 2000 (63 and $64 \times 10^{3} \mathrm{t}$, respectively) and lowest in $1996\left(17 \times 10^{3} \mathrm{t}\right)$, and averaged $43 \times 10^{3} \mathrm{t}$ (Table 5). The date of the maximum YOY $B$ ranged from 2 September (1996) to 15 October (1998) (range $=43 \mathrm{~d}$ ). In 1998, the spawning peak (1 August; Table 4 ) and $B$ peak (15 October) were the latest in the 6 yr series. Peak baywide $B$ was highest in $1998(182 \times$ $10^{3}$ t; Fig. 4a). Biomasses of YOY bay anchovy generally decreased after September. In winter 1996 to 1997 , despite lowest fall YOY $B$, baywide $B$ declined least because this year class experienced the lowest overwinter mortality (Table 4).

Daily production $(P)$ by YOY bay anchovy increased progressively from May to July-September, and decreased thereafter (Fig. 4b). Total YOY $P$ from April to October varied nearly 4 -fold among years (Table 5). It was highest in $2000\left(644 \times 10^{3} \mathrm{t}\right)$ and lowest in 1996 $\left(156 \times 10^{3} \mathrm{t}\right)$, averaging $423 \times 10^{3} \mathrm{t}$ (Table 5). Production by larval-stage bay anchovy (<21 mm TL) contributed $24 \%$ (1995 and 1998) to $40 \%$ (1996) of the summer YOY $P$, and averaged $29 \%$. The date of maximum daily $P$ ranged from 18 July (1996) to 13 September (1998) (range $=57 \mathrm{~d}$ ). Peak daily YOY $P$ was highest in $1998\left(7.1 \times 10^{3} \mathrm{t} \mathrm{d}^{-1}\right.$ on 13 September $)$ and lowest in $1996\left(1.5 \times 10^{3} \mathrm{t} \mathrm{d}^{-1}\right.$ on 18 July). Total overwinter YOY $P$ varied 7 -fold among years, and was highest in 1998 to $1999\left(77 \times 10^{3} \mathrm{t}\right)$, and lowest in 1995 to 1996 and 1996 to $1997\left(11 \times 10^{3}\right.$ t). On average, overwinter YOY $P$ accounted for only $8 \%$ of total annual YOY $P$. For an entire year, total YOY $P$ differed among years by a factor of 4.0 (Table 5). It was highest in 2000 to 2001 $\left(697 \times 10^{3} \mathrm{t}\right)$, and lowest in 1996 to $1997\left(167 \times 10^{3} \mathrm{t}\right)$.

Although contribution to predators $(C)$ of YOY bay anchovy was nearly balanced by $P$ on an annual basis, net production $\left(P_{\mathrm{n}}=\Delta B=P-C\right)$ was positive for the summer period, but negative for the overwinter period (Table 5). Annual YOY $P_{\mathrm{n}}$ was slightly positive, ranging from $6 \times 10^{3} \mathrm{t}$ in 1997-1998 to $24 \times 10^{3} \mathrm{t}$ in 2000-2001, and represents new input to age 1 to 3 spawning stock biomass in April of the following year. The date of maximum YOY $C$ occurred 10 to $17 \mathrm{~d}$ (average $14 \mathrm{~d}$ ) after that of maximum daily YOY $P$ (Table 5, Fig. 4b,c). Daily contribution to predators increased from May to August and peaked in the August to September period, before declining (Fig. 4c). The date of maximum daily YOY $C$ ranged from 31 July (1996) to 28 September (1998) (range = 59 d). Peak daily YOY $C$ was high in 1997, 1998 and 2000 (4.3 to $\left.4.9 \times 10^{3} \mathrm{t}\right)$, moderate in $1999\left(3.4 \times 10^{3} \mathrm{t}\right)$ and low in

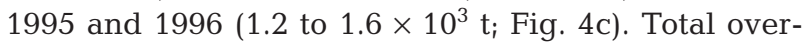
winter YOY $C$ varied nearly 14 -fold from 1995 to 2000 (Table 5). It was highest in 1998 to $1999\left(255 \times 10^{3} \mathrm{t}\right)$, and lowest in 1996 to $1997\left(18 \times 10^{3} \mathrm{t}\right)$.

\section{DISCUSSION}

\section{Immigration and overwintering}

In estimating production, we assumed that Chesapeake Bay is a relatively closed system with respect to bay anchovy immigration or emigration. The assumption may be reasonable but it was not evaluated. There may be some immigration and emigration across the

Table 5. Baywide estimates of annual biomass, production and contribution to predators by young-of-the-year bay anchovy in Chesapeake Bay from 1995 to 2000. Mean standing stock biomass $(\bar{B})$, production to mean biomass ratio $(P / \bar{B})$ of YOY bay anchovy including larval stages, and the dates of maximum (= peak) daily standing stock biomass $(B)$, daily production, and daily contribution to predators $(C)$. In addition, the $P / \bar{B}$ ratio applied only to individuals $>21 \mathrm{~mm}$ total length (TL) is estimated. The unit of $\bar{B}, P$ and $C$ is wet wt in $10^{3}$ metric tons (t). CV: coefficient of variation (\%)

\begin{tabular}{|c|c|c|c|c|c|c|c|c|c|c|c|c|c|c|c|c|}
\hline \multirow[t]{2}{*}{ Year } & \multirow{2}{*}{$\bar{B}$} & \multicolumn{3}{|c|}{-April-October } & \multicolumn{4}{|c|}{-October-April } & \multicolumn{5}{|c|}{ - Total for a year- } & \multicolumn{3}{|c|}{ Peak date } \\
\hline & & $P$ & $C$ & $P / \bar{B}$ & $\bar{B}$ & $P$ & $C$ & $P / \bar{B}$ & $\bar{B}$ & $P$ & $C$ & $P / \bar{B}$ & $\begin{array}{c}P / \bar{B}(>21 \\
\mathrm{mm} \mathrm{TL})\end{array}$ & $B$ & $P$ & $C$ \\
\hline 1995 & 24 & 203 & 155 & 8.32 & 23 & 11 & 52 & 0.49 & 24 & 214 & 207 & 9.02 & 7.18 & $09 / 30$ & $08 / 17$ & $09 / 02$ \\
\hline 1996 & 15 & 156 & 136 & 10.07 & 18 & 11 & 18 & 0.60 & 17 & 167 & 154 & 9.95 & 6.57 & $09 / 02$ & $07 / 18$ & $07 / 31$ \\
\hline 1997 & 50 & 525 & 442 & 10.42 & 31 & 24 & 102 & 0.80 & 42 & 550 & 544 & 13.23 & 9.39 & $09 / 18$ & $08 / 17$ & $08 / 27$ \\
\hline 1998 & 56 & 540 & 350 & 9.60 & 69 & 77 & 255 & 1.11 & 63 & 617 & 605 & 9.82 & 8.01 & $10 / 15$ & 09/13 & $09 / 28$ \\
\hline 1999 & 62 & 468 & 387 & 7.59 & 36 & 35 & 108 & 0.98 & 48 & 503 & 495 & 10.39 & 7.83 & $09 / 07$ & 08/04 & $08 / 14$ \\
\hline 2000 & 77 & 644 & 498 & 8.40 & 51 & 52 & 175 & 1.03 & 64 & 697 & 673 & 10.89 & 8.43 & $09 / 20$ & 08/06 & $08 / 23$ \\
\hline Mean & 47 & 423 & 328 & 9.07 & 38 & 35 & 118 & 0.84 & 43 & 458 & 446 & 10.55 & 7.90 & $09 / 20$ & $08 / 12$ & $08 / 26$ \\
\hline $\mathrm{CV}$ & 48.9 & 46.7 & 45.8 & 12.4 & 50.3 & 73.1 & 72.5 & 29.8 & 45.7 & 47.5 & 48.2 & 13.8 & 12.4 & & & \\
\hline
\end{tabular}


Bay mouth. Estimated abundance of adult bay anchovy increased substantially between the April and July periods in 1995 and 1998, and between the June to July and October periods in 1996 and 1999 (Table 2 \& Fig. 2), suggesting that adult immigration into the Bay from its tributaries or the coastal ocean may occur in some years. In 1999, the extreme case, estimated numbers of adults increased approximately 5 -fold between June and October (Table 2) and most occurred in the lower and mid-regions of the Bay, suggesting possible immigration from lower Bay tributaries, or from the coastal ocean.

Declines in abundance of YOY anchovy between October and April were attributed to overwinter mortality, which was lowest in 1996 to 1997 and highest in 1997 to 1998 and 1998 to 1999 (Table 4). Causes of overwinter losses were not identified but it is possible that emigration to tributaries or to the ocean could have contributed to losses. It is notable that bay anchovy recruitment increased sharply in 1997, after the low overwinter loss of YOY anchovy in 1996 to 1997, which contributed to a high adult stock level in April to May 1997 (Table 2).

\section{Environmental variability and bay anchovy recruitment/production}

Water temperature apparently controls YOY bay anchovy growth rate (Table 6). If the apparent relationship between temperature and growth rate were incorrect and modeled growth fit poorly (Fig. 3), then the significant correlations in Table 6 between temperature and growth would not have been generated. In years when summer water temperature was high (e.g. 1995), YOY anchovy growth rate was elevated and the back-calculated cohort birth dates shifted to dates later in the year. This may seem counterintuitive since high temperatures might be expected to promote earlyseason spawning. However, it is probable that high summer-fall water temperatures stimulate higher secondary peaks of spawning and subsequent production between July and October (see Tables 2 \& 3, and Fig. 4 for contrasting patterns between 1998 and 1999 with respect to mean temperature, number of cohorts and peak dates). The estimated dates of peak spawning, biomass, production, and contribution to predators were generally positively correlated with the regional

Table 6. Correlation coefficients of parameter estimates for young-of-the-year bay anchovy production with respect to regionspecific means of subpycnocline temperature, salinity and dissolved oxygen from 1995 to 2000 . G: the mean growth rates in wet wt $\left(\mathrm{g} \mathrm{d}^{-1}\right)$ for the young-of-the-year stage (0 to $180 \mathrm{~d}$ age). $q$ : length-specific mortality. $M_{\text {cum }}$ : cumulative mortality from egg stage to juvenile stage during the summer period $=\log$ (total number of eggs produced/total number of recruits). $S$ : spawning, $B$ : biomass, $P$ : production, $C$ : contribution to predators. Abbreviations in the row variables for abiotic factors are the following: TEM = water temperature; $\mathrm{SAL}=$ salinity; $\mathrm{OXY}=$ dissolved oxygen; 07 = June to August; 10 : October; $\mathrm{L}=$ lower Bay; M: middle Bay; U: upper Bay. MEAN_T = the annual mean subpycnocline temperature of the lower Bay region between June to August and October. ${ }^{*}$ Significant at $\alpha=0.05,{ }^{* *}$ significant at $\alpha=0.01$

\begin{tabular}{|c|c|c|c|c|c|c|c|c|c|c|}
\hline \multirow[t]{2}{*}{ Variables } & \multirow[t]{2}{*}{$G$} & \multirow[t]{2}{*}{$q$} & \multirow{2}{*}{$M_{\text {cum }}$} & \multirow[t]{2}{*}{$B$} & \multirow[t]{2}{*}{$P$} & \multirow[t]{2}{*}{$C$} & \multicolumn{4}{|c|}{ Peak date } \\
\hline & & & & & & & $S$ & $B$ & $P$ & $C$ \\
\hline TEM07L & $0.88^{*}$ & -0.14 & -0.54 & -0.03 & 0.07 & -0.04 & 0.78 & $0.82^{*}$ & 0.67 & 0.73 \\
\hline TEM07M & $0.83^{*}$ & 0.06 & -0.37 & -0.46 & -0.42 & -0.53 & 0.62 & 0.62 & 0.38 & 0.47 \\
\hline TEM07U & $0.84^{*}$ & -0.20 & -0.51 & -0.31 & -0.21 & -0.34 & 0.80 & 0.79 & 0.75 & 0.75 \\
\hline TEM10L & 0.78 & -0.46 & $-0.81^{*}$ & 0.08 & 0.07 & -0.15 & 0.67 & 0.71 & 0.51 & 0.62 \\
\hline TEM10M & 0.64 & -0.68 & $-0.87^{*}$ & 0.26 & 0.18 & -0.03 & 0.50 & 0.62 & 0.48 & 0.56 \\
\hline TEM10U & 0.46 & -0.66 & -0.77 & 0.38 & 0.25 & 0.08 & 0.27 & 0.44 & 0.27 & 0.37 \\
\hline MEAN_T & $0.97^{* *}$ & -0.35 & -0.79 & 0.03 & 0.09 & -0.11 & $0.85^{*}$ & $0.90^{*}$ & 0.70 & 0.79 \\
\hline SAL07L & -0.63 & 0.20 & 0.61 & -0.32 & -0.47 & -0.30 & -0.75 & -0.69 & -0.60 & -0.66 \\
\hline SAL07M & 0.15 & $-0.96^{* *}$ & -0.68 & 0.62 & 0.49 & 0.41 & 0.11 & 0.35 & 0.48 & 0.45 \\
\hline SAL07U & -0.33 & -0.29 & 0.03 & 0.39 & 0.16 & 0.25 & -0.63 & -0.36 & -0.45 & -0.40 \\
\hline SAL10L & 0.49 & -0.74 & -0.68 & 0.61 & 0.59 & 0.53 & 0.42 & 0.66 & 0.72 & 0.71 \\
\hline SAL10M & 0.35 & -0.55 & -0.43 & 0.47 & 0.47 & 0.47 & 0.31 & 0.51 & 0.61 & 0.57 \\
\hline SAL10U & -0.01 & -0.77 & -0.52 & $0.97^{* *}$ & $0.95^{* *}$ & $0.91^{*}$ & 0.09 & 0.28 & 0.44 & 0.41 \\
\hline OXY07L & -0.04 & 0.43 & 0.33 & $-0.88^{*}$ & $-0.87^{*}$ & $-0.89^{*}$ & -0.01 & -0.21 & -0.23 & -0.25 \\
\hline OXY07M & -0.29 & 0.65 & 0.70 & $-0.84^{*}$ & $-0.85^{*}$ & -0.72 & -0.34 & -0.47 & -0.46 & -0.50 \\
\hline OXY07U & 0.26 & 0.08 & -0.09 & -0.45 & -0.29 & -0.39 & 0.51 & 0.30 & 0.44 & 0.37 \\
\hline OXY10L & -0.51 & -0.38 & 0.05 & 0.26 & 0.20 & 0.23 & -0.31 & -0.29 & 0.00 & -0.11 \\
\hline OXY10M & -0.16 & -0.58 & -0.24 & 0.05 & -0.10 & -0.14 & -0.17 & -0.07 & 0.09 & 0.03 \\
\hline OXY10U & -0.16 & -0.29 & -0.05 & -0.29 & -0.38 & -0.42 & -0.12 & -0.13 & 0.01 & -0.05 \\
\hline$G$ & & -0.34 & -0.78 & -0.06 & 0.03 & -0.17 & $0.92^{*}$ & $0.94^{* *}$ & 0.79 & $0.86^{*}$ \\
\hline$q$ & -0.34 & & $0.83^{*}$ & -0.68 & -0.58 & -0.46 & -0.29 & -0.53 & -0.60 & -0.60 \\
\hline$M_{\text {cum }}$ & -0.78 & $0.83^{*}$ & & -0.46 & -0.45 & -0.24 & -0.72 & $-0.87^{*}$ & $-0.82^{*}$ & $-0.87^{*}$ \\
\hline
\end{tabular}


mean subpycnocline temperatures in June to August and October ( $\mathrm{r}=0.27$ to 0.90 ) or with YOY growth rate $(\mathrm{r}=0.79$ to $0.94, \mathrm{p}=0.005$ to 0.06 ) (Table 6).

Salinity may be important in controlling distribution of predators and thus survival of YOY bay anchovy. Values of $q$, the length-specific mortality for the April to October periods, were generally negatively correlated with regional mean subpycnocline-layer salinity in June to August and October (Table 6). The correlation was especially strong for the June to August subpycnocline-layer mean salinity in the middle Bay $(r=-0.96, p=0.002 ;$ Fig. 5a). There were no significant correlations between regional mean water temperatures and $q$. Biomass, production, and contribution to predators were generally positively correlated with the regional mean subpycnocline-layer salinity in June to August and October, and the correlations were especially strong for the upper Bay during October $(\mathrm{r}=0.91$ to $0.97, \mathrm{p}<0.02)$. These correlations suggest that summer-fall seasons with low freshwater input favor high survival of bay anchovy during larval and juvenile stages, possibly because high salinity controls distribution patterns of predators of YOY bay anchovy such as gelatinous organisms (scyphomedusa Chrysaora quinquecirrha and lobate ctenophore Mnemiopsis leidyi) and piscivorous fish. Wood \& Houde (2002) thought it possible that salinity changes in Chesapeake Bay may affect bay anchovy and $M$. leidyi by directly controlling $C$. quinquecirrha distribution and abundance. The 2 gelatinous species are important predators on bay anchovy eggs and larvae (Purcell et al. 1994) and, additionally, abundance of $M$. leidyi is controlled directly by $C$. quinquecirrha predation. Reproduction of $C$. quinquecirrha is reduced at low salinities (Purcell et al. 1999).

An individual-based predation model (Breitburg et al. 1999) suggested that bottom DO level can strongly affect predation mortality on fish larvae by inducing depth-specific shifts in concentrations of predators and prey and trophic interactions. The model results indicated that predation mortality on fish larvae may increase at high bottom DO levels. Our correlation analyses did not indicate significant correlations between $q$ or YOY growth rate of bay anchovy larvae and subpycnocline-layer mean DO in summer from 1995 to 2000 (Table 6).

We assumed that summer production level of YOY bay anchovy is ultimately determined by SSB, growth rate and $q$ (Eq. 11). Thus, it is expected that growth rate or $q$ alone would not be significantly correlated with the summer production level. For example, in 1995 the mean growth rate $\left(\mathrm{mm} \mathrm{d}^{-1}\right)$ from April to October was highest among the $6 \mathrm{yr}$ (Table 3), but the summer production level of YOY bay anchovy was second lowest (Table 5), because the SSB in April to May and the subsequent egg production was lowest in 1995 (Table 4).

It is possible that the growth rates we estimated represent the mean growth of YOY individuals that survived, not of all individuals that were hatched. If this were the case, it is probable that actual mean growth rates for larval stages were lower than our estimates of mean growth rate for survivors as a consequence of growth-rate selective mortality (Meekan \& Fortier 1996).

The relation between length and instantaneous mortality expressed in Eq. 6 indicates that, if the value of $q$ is held constant, fast growth is one mechanism to reduce cumulative mortality of a bay anchovy cohort
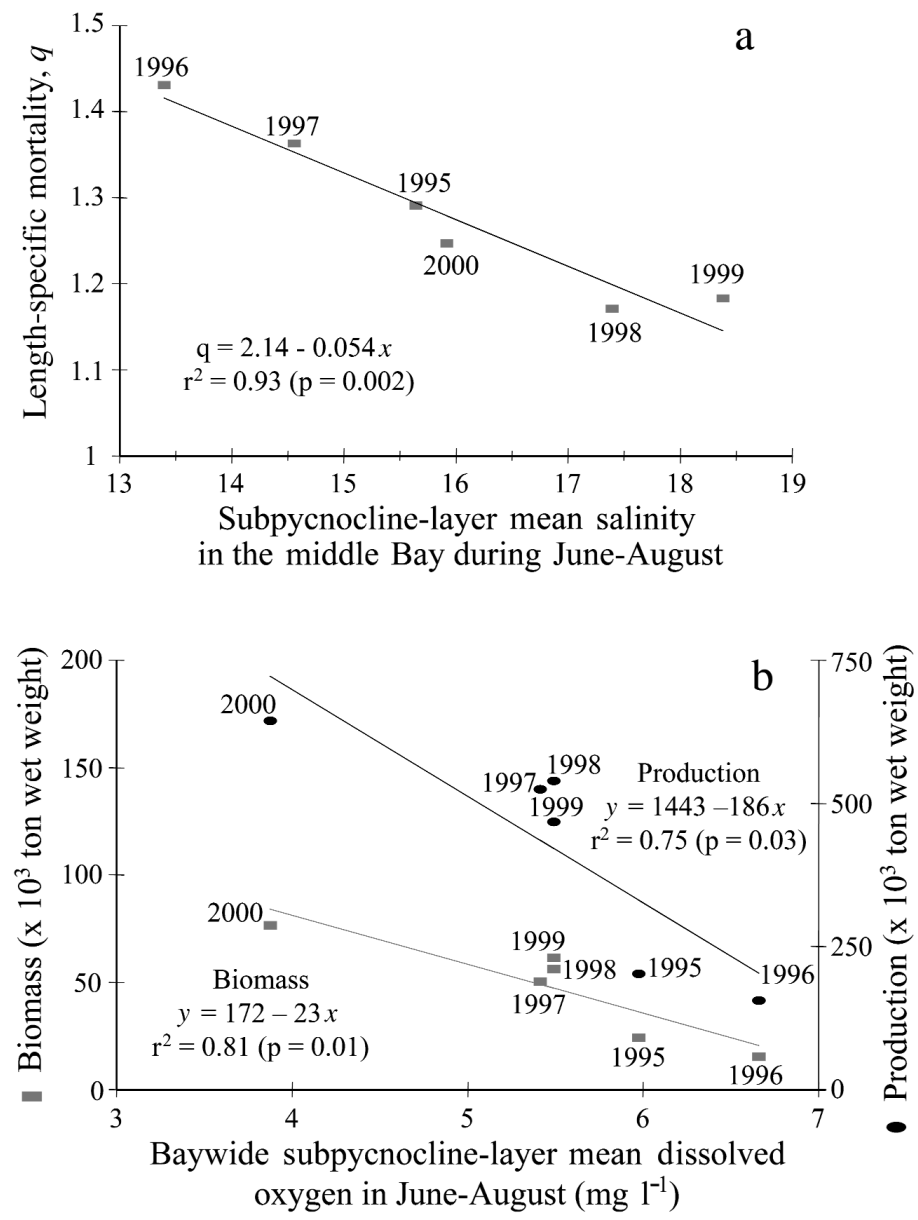

Fig. 5. (a) Relationship between length-specific mortality $(q)$ in April to October and subpycnocline-layer mean salinity in the middle Bay during June to August. Dissolved oxygen (DO) and salinity data are from the Trophic Interactions in Estuarine Systems (TIES) Program CTD casts, 1995 to 2000 (www.chesapeake.org/ties) (b) Relationships between mean biomass and production of YOY bay anchovy in April to October and subpycnocline-layer mean DO level in Chesapeake Bay during the June to August period from 1995 to 2000 
(Cowan et al. 1996). Based on the mean larval growth rate of $0.80 \mathrm{~mm} \mathrm{~d}^{-1}$ from age 0 to $35 \mathrm{~d}$ (Table 3 ) and mean $q=1.28$ for 1995 to 2000 (Table 4), we estimated from Eq. 6 that on average $0.22 \%$ of eggs survive to $29 \mathrm{~mm}$ TL juveniles at $35 \mathrm{~d}$. A simple sensitivity analysis shows that larval survival rate and subsequent recruitment level of bay anchovy potentially are very sensitive to larval growth rate. For example, through its effect on length-specific mortality, a decrease in mean growth rate of $10 \%$ would reduce $35 \mathrm{~d}$ survival by $34 \%$, while an increase in mean growth rate of $10 \%$ would increase $35 \mathrm{~d}$ survival by $42 \%$. Variability in bay anchovy larval growth rate, which is dependent on water temperature and food availability (Rilling \& Houde 1999b), if accompanied by length-specific mortality, could be sufficient to generate levels of recruitment variability observed for bay anchovy in Chesapeake Bay (9-fold in 1995 to 2000, Jung \& Houde 2004).

The level of $q$ may be an indicator of potential predation, which is determined by population abundances and spatial distribution of predators. Eq. 6 assumes that growth rate alone can determine mortality if $q$ is held constant. Therefore, insignificant correlations of YOY growth rate with respect to cumulative mortality and YOY production, without accounting for $q$, were not unexpected (Table 6). Cumulative mortality was positively and significantly correlated with $q(\mathrm{r}=0.83$, $\mathrm{p}=0.04$ ), but was marginally and negatively correlated with YOY growth rate $(r=-0.78, p=0.07)$. These correlations suggest that the level of $q$, rather than YOY growth rate, accounts for a major part of the variability in cumulative mortality of YOY bay anchovy from egg to juvenile stages. A sensitivity analysis shows that recruitment level of bay anchovy potentially is very sensitive to the level of $q$. For example, a decrease in $q$ of $10 \%$ would increase 35 d survival by $85 \%$, while an increase in $q$ of $10 \%$ would reduce 35 d survival by $46 \%$.

We hypothesize that variation in cumulative predation mortality, which is controlled by both growth rate (i.e. stage duration) and $q$ (i.e. level of potential predation), is the mechanism that generates the relationship between DO and production of YOY bay anchovy (Fig. 5b). Low subpycnocline DO conditions can result from high primary production and entrapment of organic matter below the pycnocline where low-DO or hypoxic conditions can develop. The high production of YOY bay anchovy at low DO suggests that enhanced zooplankton production also occurred at low DO, which supported faster larval growth rate and thus lower cumulative mortality if $q$ were constant. Levels of biomass, production and contribution to predators of YOY bay anchovy from April to October were consistently negatively correlated with lower and mid-
Bay mean DO ( $\mathrm{r}=-0.72$ to -0.89 ; Table 6 ; Fig. $5 \mathrm{~b})$ but were not significantly correlated with adult SSB in April to May and June to August ( $r=0.27$ to 0.68 , $p$ > $0.13)$. This observation indicates that dynamics of larval and juvenile stages are more important in determining production level of YOY bay anchovy than is total fecundity. Auth (2003) reported a positive correlation between growth rate of bay anchovy larvae for Chesapeake Bay in 1995 to 1999 and YOY recruitment level in October. In our study, it appears that temperature and DO levels were important controllers of growth rate, while salinity may cause shifts in spatial distribution of predators and thus may control predation mortality of YOY bay anchovy that is indicated by interannual variability in the value of $q$.

\section{Comparisons}

Previous research on bay anchovy population biology and production in Chesapeake Bay was limited to regional analyses. Our results are baywide and span a 6 yr timeframe, allowing comparisons that were not possible previously.

\section{Abundance}

Our abundance estimates are generally higher than the trawl-survey relative abundance estimates of Wang \& Houde (1995) for the upper-mid and mid Chesapeake Bay in April 1990 to October 1991. Their regional estimate, expressed as mean density (number per $\mathrm{m}^{3}$ ), in April 1990 was $0.023 \mathrm{~m}^{-3}$. Our baywide estimates in April were higher, ranging from 0.04 in 1995 to $0.23 \mathrm{~m}^{-3}$ in 1997 (Table 2). In October 1990, Wang \& Houde (1995) reported $0.427 \mathrm{~m}^{-3}$ for anchovy $>21 \mathrm{~mm} \mathrm{TL}$, while our estimates were much higher, ranging from 0.60 in October 1996 to $5.31 \mathrm{~m}^{-3}$ in October 1998.

\section{Biomass}

Our estimates of bay anchovy biomass in October (>30 mm TL) ranged from $4.9 \mathrm{~g} \mathrm{~m}^{-2}$ (baywide biomass $=27 \times 10^{3}$ metric $\left.\mathrm{t}\right)$ in 1996 to $35.0 \mathrm{~g} \mathrm{~m}^{-2}(=193 \times$ $10^{3}$ metric $\mathrm{t}$ ) in 1998 , and averaged $18.9 \mathrm{~g} \mathrm{~m}^{-2}$ (= $137 \times$ $10^{3}$ metric t) from 1995 to 2000 . Our biomass density estimates are on average about $50 \%$ higher than the regional estimates of Luo \& Brandt (1993), who estimated bay anchovy mean biomass from hydroacoustics data in a segment of mid-Chesapeake Bay during September and November 1989 as 10.7 and $14.7 \mathrm{~g} \mathrm{~m}^{-2}$, respectively. 


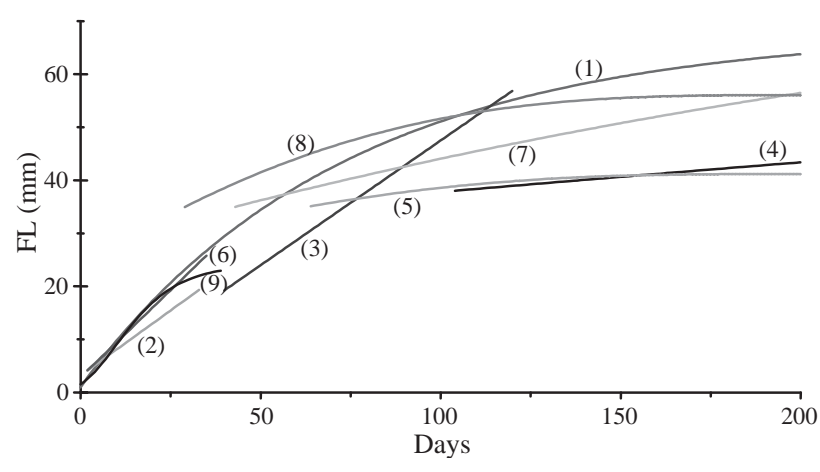

Fig. 6. Comparisons of growth by young-of-the-year bay anchovy. (1) This study, averaged for 1995 to 2000; (2) Leak \& Houde (1987), constant growth rate, larval stage only; (3) Zastrow et al. (1991), constant growth rate; (4) Newberger \& Houde (1995), traditional von Bertalanffy growth model (VBGF); (5) Newberger \& Houde (1995), seasonal VBGF; (6) Rilling \& Houde (1999b), constant growth rate, larval stage only; (7) Lapolla (2001), traditional VBGF; (8) Lapolla (2001), seasonal VBGF; (9) Auth (2003), Gompertz growth function for larval stages. FL: fork length

\section{Growth}

We compared the growth models fit to YOY anchovy data for summer periods from 1995 to 2000 with those of past studies (Fig. 6). Our synthesized VBGF gave results that are broadly comparable with other studies. Our mean growth rate from 0 to $180 \mathrm{~d}$ was higher than most rates estimated in past studies (Fig. 6). However, if YOY growth rates were lower than our estimates (Table 3), then the back-calculated dates of peak spawning activity would be earlier than observed peak dates (Luo \& Musick 1991, Zastrow et al. 1991).

\section{Mortality}

We compared our values of $q$ (Table 4) for the 'summer' (April to October) period with those derived from other studies on size-specific mortality for fish, or specifically for bay anchovy (Fig. 7). The curves in Fig. 7 indicate the uncertainties in estimating natural mortality. The generalized size-specific mortality formulations of Peterson \& Wroblewski (1984) and McGurk (1986) were derived from composites of marine fish species, some invertebrates and marine mammals. It is not surprising that their models (a and $b$, respectively) do not describe the sizespecific mortality of bay anchovy. We applied Beyer's (1989) model (Eq. 6) to fit length-specific mortality rates of bay anchovy from egg to adult stages for past studies in Chesapeake Bay (Fig. 7, curve c). In that model fit, the estimated value of $q$ was $1.90 \pm 0.16$, a higher value than our estimate of $1.28 \pm 0.04$ derived from 1995 to 2000 trawl data. Houde (1997) derived an estimate of weight-specific mortality for bay anchovy larvae (Fig. 7, curve e) that was higher than other rates from 'past' studies. The higher estimate (Houde 1997) apparently is explained by exclusion of egg mortality data. Wang \& Houde (1995) also estimated or derived mortalities from regional collections of bay anchovy in Chesapeake Bay for larval to adult stages. Fitting their length-specific mortality rates to the Equation 6 model (Fig. 7, curve d) gives $q=1.45 \pm 0.09$, a value only slightly higher than our estimate. MacGregor \& Houde (1996) reported length-specific mortality values of bay anchovy larvae that ranged from 0.83 to 1.98 (mean $q=1.24$ in $\mathrm{SL}_{1}=$ 1.10 in TL) in July 1988 for mid-Chesapeake Bay.

\section{Production to mean biomass ratio}

The ratio $P / \bar{B}$ is an index of productive potential (Banse \& Mosher 1980). Despite high interannual variability in mean biomass, production and contribution to predators by YOY bay anchovy (coefficients of variation, $\mathrm{CV}=45.7$ to $48.2 \%$, Table 5$), P / \bar{B}$ was relatively stable $(\mathrm{CV}=13.8 \%$ for egg to juvenile stages and $12.4 \%$ for the juvenile stage $>21 \mathrm{~mm}$ TL). Wang \& Houde (1995), based on samples only from mid-

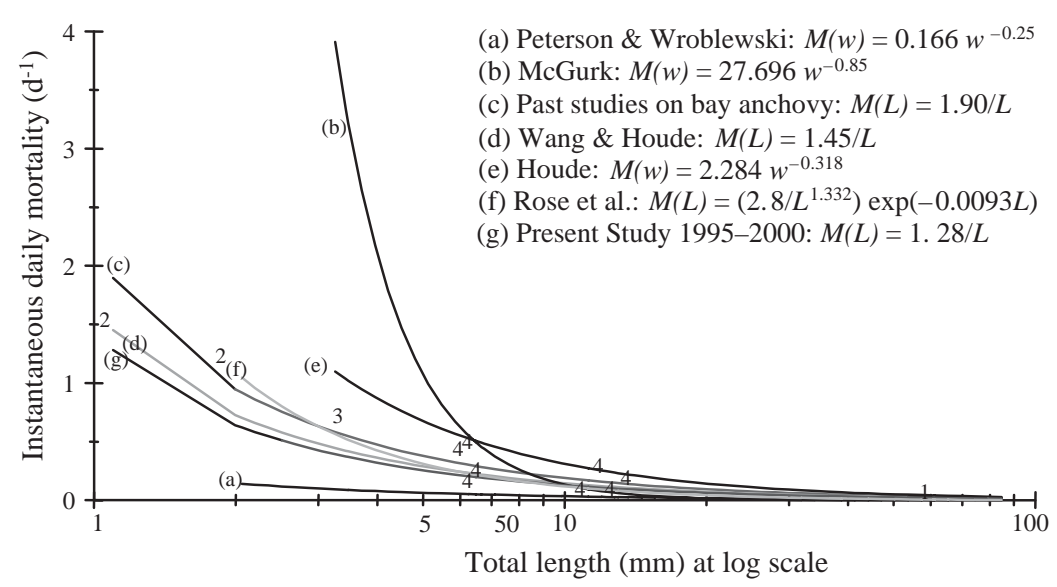

Fig. 7. Instantaneous mortality $(q)$ of bay anchovy in Chesapeake Bay predicted by several models. Lines denote predicted mortalities based on models indicated by letter: (a) Peterson \& Wroblewski (1984); (b) McGurk (1986); (c) Beyer's model (1989), fit for past studies on bay anchovy (1: Newberger \& Houde 1995, 2: Dorsey et al. 1996, 3: MacGregor \& Houde 1996, 4: Rilling \& Houde 1999b); (d) Beyer's model, fit to mortality data from Wang \& Houde (1995) (data points are not shown); (e) Houde (1997); (f) Rose et al. (1999); (g) Beyer's model (1989), applied to present study and averaged for the 1995 to 2000 period. See Table 1 for definition of variables 
Chesapeake Bay, estimated bay anchovy annual $P / \bar{B}$ $=8.07$. Our estimates are considerably higher, ranging from 9.02 (1995) to 13.23 (1997), and averaging 10.55 (Table 5). When including only the 'summer' (April to October) period, $P / \bar{B}$ ranged from 7.59 (1999) to 10.42 (1996), averaging 9.07. If we had excluded the highly productive larval stages $(<21 \mathrm{~mm}$ TL), annual $P / \bar{B}$ is lower, ranging from 6.57 (1996) to 9.39 (1997), and averaging 7.90 (Table 5). Our high estimate of $P / \bar{B}$ for bay anchovy in Chesapeake Bay compared to other fishes is explained largely by the fact that few studies on fish $P / \bar{B}$ (Banse \& Mosher 1980) included production by fast-growing larval and postlarval stages. Our estimated production by bay anchovy larvae $(<21 \mathrm{~mm} \mathrm{TL})$ contributed, on average, $38 \%$ of the 'summer' production by YOY bay anchovy from 1995 to 2000.

\section{Production}

Luo \& Brandt (1993) applied a bioenergetics model to estimate biomass, production, and contribution to predators by bay anchovy from age $40 \mathrm{~d}$ (= ca. $32 \mathrm{~mm}$ TL based on our VBGF) to $1.5 \mathrm{yr}$ in mid-Chesapeake Bay (annual $\mathrm{p}=30770 \mathrm{~kg} \mathrm{~km}{ }^{-2}$ ) after assuming a constant annual mortality of $95 \%$ (i.e. annual cumulative $M=3.0$ ). Our estimates of $P$ by YOY bay anchovy $>32 \mathrm{~mm}$ TL were variable among years, ranging from 11756 to 65937 (mean $=41527) \mathrm{kg} \mathrm{km}^{-2}$. Luo \& Brandt's (1993) estimate is comparable to and within the range of our estimates.

The estimated mean annual production (baywide) of YOY bay anchovy was $458 \times 10^{3}$ metric $\mathrm{t}=830 \mathrm{~kg} \mathrm{ha}^{-1}$ $\mathrm{yr}^{-1}$. This estimate is $30 \%$ higher than an estimate for total fish production in Chesapeake Bay by Houde \& Rutherford (1993) (= $\left.646 \mathrm{~kg} \mathrm{ha}^{-1} \mathrm{yr}^{-1}\right)$, based on primary production, presumed trophic transfer efficiency of $10 \%$, and average fish production at 2.5 trophic levels above primary producers. Our estimate of YOY bay anchovy production (approximately 2.0 trophic levels above primary producers) corresponds to $2.0 \%$ of the net primary production reported for Chesapeake Bay (= $408 \mathrm{~g} \mathrm{C} \mathrm{m}^{-2} \mathrm{yr}^{-1}$; Harding et al. 2002). Assuming that ecological efficiency for bay anchovy is $10 \%$, YOY bay anchovy might have consumed $4.6 \times 10^{6} \mathrm{t}$ of zooplankton annually, on average, from 1995 to 2000 (multiplying $P$ by 10).

Our estimated potential contribution of YOY bay anchovy to predators, assuming that all mortality was from predation, averaged for 1995 to 2000 , was $446 \times 10^{3}$ t. If transfer efficiency is about $10 \%$, this estimate is equivalent to $45 \times 10^{3}$ t of predator production and corresponds to $15 \%$ of annual commercial landings of fishes and invertebrates from the Chesapeake Bay (averaged landings for 1995 to $2000=296 \times 10^{3}$ t, www.st.nmfs.gov/ commercial/landings/annual_landings.html).

\section{CONCLUSIONS}

Our study has set the stage for future synthesis research on the links between bay anchovy and its predators and prey. Evaluating zooplankton abundances and production in Chesapeake Bay, in combination with anchovy prey consumption and bioenergetics information (Vazquez-Rojas 1989, Klebasko 1991), will allow stage-based and spatially explicit bioenergetics models to be developed for bay anchovy. Another size-based approach, based on biomass-size spectra, presently is being evaluated to estimate biomass, production, and consumption by key fish species in Chesapeake Bay (Jung \& Houde 1999, Jung 2002). Such research is needed to support resource management goals for Chesapeake Bay that require development of multi-species fisheries management within the next decade (Miller et al. 1996, Houde et al. 1998, Chesapeake Executive Council 2000).

Size-based approaches to simplify estimation of growth and survival rates have advantages and drawbacks in fish production and recruitment studies (Peterson \& Wroblewski 1984, McGurk 1986, Beyer 1989, Pope et al. 1994, Heath 1996). Because we lacked sufficient information on the dynamics of egg and larval stages of bay anchovy at appropriate temporal and spatial scales, we approximated growth and mortality during early-life stages from the juvenile-stage properties, undertook a synthesis of results from past studies, and simplified processes based on allometric relationships. This approach assumed 'constant' within-year functions of growth and mortality for life stages of bay anchovy in our analysis. Therefore, derived parameters represented average values for a life stage, selected group, or period within a year. It is probable that parameters such as $L_{\infty}$ (dependent on food availability and temperature) and $q$ (sensitive to predation) actually are to an extent variable and responsive to oceanographic and biological conditions that shift within a single production cycle.

Recognizing the caveats, our study provided 6 annual, baywide estimates and demonstrated how annually variable environmental conditions can affect observed variability in recruitment and production of bay anchovy. We believe that allometric scaling approaches provide a practical method to investigate population dynamics in relation to hydrological variability in the presence of complex trophic interactions. These approaches potentially can be applied in evolving plans for multi-species and ecosystem-based fisheries management in Chesapeake Bay. 
Acknowledgements. We thank S. Leach, G.C. Rilling, J. Cleveland, E. North, A. Madden, D. O'Brien, B. Pearson, D. Craige, T. Auth, and the crew of the RV Cape Henlopen for assistance in field surveys. Field surveys had been conducted during the project 'Trophic Interactions in Estuarine Systems (TIES)' (www.chesapeake.org/ties/ties.html), a Land Margin Ecosystem Research (LMER) program, supported by the U.S. National Science Foundation Grant DEB94-12113. Further analysis and synthesis were supported by NOAA Coastal Ocean Project Grant NA17OP2656 and by a NOAA Chesapeake Bay Office award NA07FU053. This is Contribution No. 3780 of the University of Maryland Center for Environmental Science, Chesapeake Biological Laboratory.

\section{LITERATURE CITED}

Auth (2003) Interannual and regional patterns of abundance, growth, and feeding ecology of larval bay anchovy in Chesapeake Bay. MS thesis, University of Maryland, College Park, MD

Baird D, Ulanowicz RE (1989) The seasonal dynamics of the Chesapeake Bay ecosystem. Ecol Monogr 59:329-364

Banse K, Mosher S (1980) Adult body mass and annual production/biomass relationships of field populations. Ecol Monogr 50:355-379

Beverton RJH (1994) Notes on the use of theoretical models in the study of the dynamics of exploited fish populations. Marine Fisheries Section, American Fisheries Society, Beaufort, NC

Beyer J (1989) Recruitment stability and survival: simple sizespecific theory with examples from the early life dynamics of marine fish. Dana 7:45-147

Bhattacharya CG (1967) A simple method of resolution of a distribution into Gaussian components. Biometrics 23: 115-135

Breitburg DL, Rose KA, Cowan JH (1999) Linking water quality to larval survival: predation mortality of fish larvae in an oxygen-stratified water column. Mar Ecol Prog Ser 178:39-54

Chesapeake Executive Council (2000) Chesapeake 2000 agreement. Chesapeake Bay Program, Annapolis, MD

Cowan JH, Houde ED, Rose KA (1996) Size-dependent vulnerability of marine fish larvae to predation: an individual-based numerical experiment. ICES J Mar Sci 53: 23-37

Cowan JH, Rose KA, Houde ED, Wang SB, Young J (1999) Modeling effects of increased larval mortality on bay anchovy population dynamics in the mesohaline Chesapeake Bay: evidence for compensatory reserve. Mar Ecol Prog Ser 185:133-146

Cronin WB (1971) Volumetric, areal, and tidal statistics of the Chesapeake bay estuary and its tributaries. Chesapeake Bay Institute, Johns Hopkins University, Baltimore, MD

Dorsey SE, Houde ED, Gamble JC (1996) Cohort abundances and daily variability in mortality of eggs and yolk-sac larvae of bay anchovy, Anchoa mitchilli, in Chesapeake Bay. Fish Bull US 94:257-267

Harding LW, Mallonee ME, Perry ES (2002) Toward a predictive understanding of primary productivity in a temperate, partially stratified estuary. Estuar Coast Shelf Sci 55: $437-463$

Hartman KJ, Brandt SB (1995) Predatory demand and impact of striped bass, bluefish, and weakfish in the Chesapeake Bay: applications of bioenergetics models. Can J Fish Aquat Sci 52:1667-1687
Heath MR (1996) The consequences of spawning time and dispersal patterns of larvae for spatial and temporal variability in survival to recruitment. In: Watanabe $Y$, Yamashita Y, Oozeki Y (eds) Survival strategies in early life stages of marine resources. AA Balkema, Rotterdam, p 175-207

Houde ED (1987) Fish early life dynamics and recruitment variability. Am Fish Soc Symp 2:17-29

Houde ED (1996) Evaluating stage-specific survival during the early life of fish. In: Watanabe Y, Yamashita Y, Oozeki $\mathrm{Y}$ (eds) survival strategies in early life stages of marine resources. Proceedings of an international workshop. Yokohama. Japan 11-14 October 1994. AA Balkema, Rotterdam, p 51-66

Houde ED (1997) Patterns and trends in larval-stage growth and mortality of teleost fish. J Fish Biol 51 (Suppl A):52-83

Houde ED, Rutherford ES (1993) Recent trends in estuarine fisheries: prediction of fish production and yield. Estuaries 16:161-176

Houde ED, Zastrow CE (1991) Bay anchovy. In: Funderburk SL, Mihursky JA, Jordan SJ, Riley D (eds) Habitat requirements for Chesapeake Bay living resources. Living Resources Subcommittee, Chesapeake Bay Program, Annapolis, MD, p 8.1-8.14

Houde ED, Fogarty MJ, Miller TJ (1998) Prospects for multispecies fisheries management in Chesapeake Bay. A Workshop. April 1-3 1998. STAC Publication 98-002, Solomons, MD

Jung S (2002) Fish community structure and the spatial and temporal variability in recruitment and biomass production in Chesapeake Bay. PhD thesis, University of Maryland, College Park, MD

Jung S, Houde ED (1999) Diversity, abundance, and biomass size spectra of pelagic fish in Chesapeake bay. ICES CM 1999/X:04 Ref. X (Poster). www.chesapeake.org/ties/ mwt/ices1999/index.htm

Jung S, Houde ED (2004) Recruitment and spawning-stock biomass distribution of bay anchovy (Anchoa mitchilli) in Chesapeake Bay. Fish Bull US. 102:63-77

Kerr SR, Dickie LM (2001) The biomass spectrum: a predatorprey theory of aquatic production. Columbia University Press, New York

Klebasko MJ (1991) Feeding ecology and daily ration of bay anchovy, Anchoa mitchilli in the mid-Chesapeake Bay. MS thesis, University of Maryland, College Park, MD

Lapolla AE (2001) Bay anchovy Anchoa mitchilli in Narragansett Bay, Rhode Island. I. Population structure, growth and mortality. Mar Ecol Prog Ser 217:93-102

Leak JC, Houde ED (1987) Cohort growth and survival of bay anchovy Anchoa mitchilli larvae in Biscayne Bay, Florida. Mar Ecol Prog Ser 37:109-122

Luo J, Brandt SB (1993) Bay anchovy Anchoa mitchilli production and consumption in mid-Chesapeake Bay based on a bioenergetics model and acoustic measurement of fish abundance. Mar Ecol Prog Ser 98:223-236

Luo J, Musick J (1991) Reproductive biology of the bay anchovy in Chesapeake Bay. Trans Am Fish Soc 120: 701-710

MacGregor JM, Houde ED (1996) Onshore-offshore pattern and variability in distribution and abundance of bay anchovy Anchoa mitchilli eggs and larvae in Chesapeake Bay. Mar Ecol Prog Ser 138:15-25

McGurk MD (1986) Natural mortality of marine pelagic fish egg and larvae: role of spatial patchiness. Mar Ecol Prog Ser 34:227-242

Meekan MG, Fortier L (1996) Selection for fast growth during 
the larval life of Atlantic cod Gadus morhua on the Scotian Shelf. Mar Ecol Prog Ser 137:25-37

Miller TJ, Houde ED, Watkins E (1996) Chesapeake Bay fisheries: prospects for multispecies management and sustainability. Scientific and Technical Advisory Committee of the Chesapeake Bay program. Chesapeake Research Consortium Publication 154B, Edgewater, MD

Newberger TA, Houde ED (1995) Population biology of bay anchovy Anchoa mitchilli in the mid Chesapeake bay. Mar Ecol Prog Ser 116:25-37

Peterson I, Wroblewski JS (1984) Mortality rate of fishes in the pelagic ecosystem. Can J Fish Aquat Sci 41:1117-1120

Pope JG, Shepherd JG, Webb J (1994) Successful surf-riding on size spectra: the secret of survival in the sea. Philos Trans R Soc Lond B 343:41-49

Purcell JE, Nemazie DA, Dorsey SE,Houde ED, Gamble JC (1994) Predation mortality of bay anchovy Anchoa mitchilli eggs and larvae due to scyphomedusae and ctenophores in Chesapeake Bay. Mar Ecol Prog Ser 114:47-58

Purcell JE, White JR, Nemazie DA, Wright DA (1999) Temperature, salinity and food effects on asexual reproduction and abundance of the scyphozoan Chrysaora quinquecirrha. Mar Ecol Prog Ser 180:187-196

Rilling GC, Houde ED (1999a) Regional and temporal variability in distribution and abundance of bay anchovy (Anchoa mitchilli) eggs, larvae, and adult biomass in the Chesapeake Bay. Estuaries 22:1096-1109

Rilling GC, Houde ED (1999b) Regional and temporal variability in growth and mortality of bay anchovy, Anchoa

Editorial responsibility: Otto Kinne (Editor),

Oldendorf/Luhe, Germany mitchilli, larvae in Chesapeake Bay. Fish Bull US 97: 555-569

Rose KA, Cowan JH, Clark ME, Houde ED, Wang SB (1999) An individual-based model of bay anchovy population dynamics in the mesohaline region of Chesapeake Bay. Mar Ecol Prog Ser 185:113-132

SAS Institute Inc (1989) SAS/STAT user's guide, Version 6, 4th edn. SAS Institute Inc., Cary, NC

Vazquez-Rojas AV (1989) Energetics, trophic relationships and chemical composition of bay anchovy, Anchoa mitchilli in the Chesapeake Bay. MS thesis, University of Maryland, College Park, MD

Wang SB, Houde ED (1995) Distribution, relative abundance, biomass and production of bay anchovy Anchoa mitchilli in the Chesapeake Bay. Mar Ecol Prog Ser 121:27-38

Wang SB, Cowan JH, Rose KA, Houde ED (1997) Individualbased modelling of recruitment variability and biomass production of bay anchovy in mid-Chesapeake Bay. J Fish Biol 51 (Suppl A):121-134

Wood RJ, Houde ED (2002) Variability in the dynamics of forage fish abundances in Chesapeake Bay: retrospective analysis, models and synthesis. In: Orner DM (ed) Chesapeake Bay fisheries research program symposium report. 2002. National Oceanic and Atmospheric Administration Chesapeake Bay Office, Annapolis, MD, p 43-52

Zastrow CE, Houde ED, Morin LG (1991) Spawning, fecundity, hatch-date frequency and young-of-the-year growth of bay anchovy Anchoa mitchilli in mid-Chesapeake Bay. Mar Ecol Prog Ser 73:161-171

Submitted: September 9, 2003; Accepted: June 22, 2004

Proofs received from author(s): September 23, 2004 